REVIEW ESSAY

\title{
The State, the Gentry, and Local Institutions: The Song Dynasty and Long-Term Trends from Tang to Qing*
}

Cunshe chuantong yu Ming Qing shishen: Shanxi Zezhou xiangtu shehui de zhidu bianqian 村社傳 統與明清士紳: 山西澤州鄉土社會的制度變遷 (Village Worship Associations and the Gentry in Ming and Qing Times: Institutional Transformations in the Local Society of Zezhou, Shanxi). By Du ZhEngzhen 杜正貞. Shanghai: Shanghai cishu chubanshe, 2007. 348 pp. CNY 30.00 (paper).

The Destruction of the Medieval Chinese Aristocracy. By Nicolas Tackett. Cambridge, Mass.: Harvard University Asia Center, 2014. xiv + 281 pp. \$49.95 (cloth), \$25.00 (paper).

Kin Gen jidai no kahoku shakai to kakyo seido: Mō hitotsu no “shijin sō” 金元時代の華北社会と 科挙制度—もう一つの「士人層」(Society and the Examination System in North China during the Jin-Yuan Period: Another “Literati Stratum”). By IrYama Tomoyasu 飯山知保. Tokyo: Waseda daigaku shuppanbu, 2011. xi + 464 pp. JPY 8,900 (cloth).

The Making of a New Rural Order in South China: I. Village, Land, and Lineage in Huizhou, 9001600. By Joseph P. McDermott. Cambridge: Cambridge University Press, 2013. xvi + 466 pp. \$102.00, £67.00 (cloth), \$34.99, £22.99 (paper), \$28.00, £21.60 (ebook).

Negotiated Power: The State, Elites, and Local Governance in Twelfth- to Fourteenth-Century China. By SukHeE LeE. Cambridge, Mass.: Harvard University Asia Center, 2014. xiii + 347 pp. \$49.95, £39.95 (cloth).

Reviewed By Song Chen, Bucknell University song.chen@ bucknell.edu doi: $10.1017 /$ jch. 2016.30

Historians have long aspired to see beyond the rise and fall of dynasties to the longue duree and the major changes over time in Chinese society. The five empirically rich and theoretically sophisticated books discussed in this essay all share this goal. While they make distinct contributions, they have in common close attention to the relationships between the state, the elite, and local institutions between the late Tang and Qing periods. Reading them together encourages rethinking the state-and-society issues that historians have been debating for a generation. In this essay, after a brief summary of each book's major contributions, I suggest ways they help us conceptualize the long-term processes of continuity and change from the late Tang to the Qing.

In his book The Destruction of the Medieval Chinese Aristocracy, Nicolas Tackett argues that the Huang Chao 黃巢 Rebellion (875-84) profoundly changed the nature of the Chinese political elite by delivering a deadly blow to the great aristocratic families that had, until then, maintained

\footnotetext{
*Acknowledgement: I wish to express my gratitude to Professors Patricia Ebrey and Beverly Bossler for their valuable comments and suggestions which have greatly contributed to the development and editorial revision of this essay.
} 
political influence for six centuries. In a direct challenge to conventional wisdom, Tackett argues that the aristocracy of the ninth century was, in essence, a "capital elite" constituted by only a small subgroup of those who claimed aristocratic ancestry - a subgroup which distinguished itself primarily by its monopoly over government offices, its geographic concentration in the capital, and its capital-centered marriage networks. Tackett contrasts this capital elite with a "provincial elite" residing outside the capital region, whose members rarely held offices or had influence beyond the local arena, despite their claims of descent from great aristocratic clans (84-87). The political elite's close ties to the capital were key to its political prominence, but they also sowed the seeds for the elite's own demise, making it easy prey during the bloody massacres and political purges of the closing years of the ninth century $(218-27,233)$.

For some time it has been widely accepted that the demise of the Tang aristocracy and the subsequent expansion of the civil service examinations in time fostered the rise of local literati as a new type of sociopolitical elite, one that provided both leadership in local society and manpower in the imperial bureaucracy. This narrative, Iiyama Tomoyasu 飯山知保 argues, risks viewing history as a linear progression and simplifies historical development after the Tang in a way that unduly privileges the experience of South China. His book Kin Gen jidai no kahoku shakai to kakyo seido: Mō hitotsu no “shijin sō” 金元時代の華北社会と科挙制度——う一つの「士人層」 (Society and the Examination System in North China during the Jin-Yuan Period: Another "Literati Stratum") complicates this conventional narrative by telling an alternative story focusing on the north. First, he problematizes the relationship between Confucian education, sinicization, and leadership in local society. Although a large number of Jurchens participated in Confucian education during the Jin, argues Iiyama, they maintained their ethnic identity and formed a social group distinct from their Han neighbors. Their Confucian education did not make them more respected leaders of local society, but it did function like a social safety net that provided some stipends and some chances of gaining office at a time when demographic expansion and decades of peace deprived many of alternative routes to power and wealth. Throughout the Jin, "Jurchen Confucian scholars" (Joshin jushi 女真儒士) remained distinct from the Han local literati (zairai shijin 在來士人). They were integrated into the Chinese society only after the Mongol conquest destroyed their social organization and hierarchy (146-47). Likewise, Iiyama argues, the impact of Confucian education on the ethnic and cultural identity of Mongol garrison families should not be overstated. Only a small number of these families sent their sons to study in the Directorate of Education or had them participate in the civil service examinations, and those who did so saw it only as a strategic choice for maintaining their political status at a time when attaining office through military and clerical service became difficult (414-15, 426-27).

Even the Chinese literati living under the Jin and Yuan, argues Iiyama, contrasted sharply with those under the Southern Song. Not only was their population much smaller than in the Southern Song, but they were also more subordinated to the state. The Jin and Yuan jealously defended the state's monopoly of control (ichigenteki na tōchi一元的な統治) over the literati, refusing to grant them any fiscal, legal, or social privileges that might help them build up their own power base in local society, thereby continuing a Chinese political tradition dating back to the Qin dynasty. It was the Southern Song, weakened by the constant threat from the Jurchens, that diverged from this tradition, trying to appease local literati by accepting their claims to various "customary privileges" (kanshüteki na tokken 慣習的な特権, 205) and their leadership in local society. The dynamics between state and local society under the Southern Song, therefore, were qualitatively different (ishitsu 異質) from earlier periods, but it was also the Southern Song dynamics that were eventually introduced into North China by the Ming state, which had itself originated from the Jiangnan region. Iiyama's account of long-term historical change, therefore, is in line with that of earlier scholars who characterize the Southern Song as a period when the state was impotent and the literati dominated local society, presaging the state-society relationship of the Ming-Qing period. 
It is this view of the Southern Song with which Sukhee Lee takes issue in Negotiated Power: The State, Elites, and Local Governance in Twelfth- to Fourteenth-Century China. In contrast to liyama, Lee is more reluctant to give himself over to grand narratives that focus on the longue durée. In his book Negotiated Power, he presents a lucid account of the state, the elites, and the roles they played in Mingzhou 明州 (now Ningbo, Zhejiang) during the Southern Song and Yuan (1271-1368). He stresses continuity, not change, in the elite's marriage patterns and their active pursuit of government connections from the Northern Song through the Yuan. He does point out, however, that the literati and officeholding population of Mingzhou increased dramatically in the Southern Song and that they also became highly active in asserting their collective identity and lending their voices to the local administration. But they were not separate from the state. Lee demonstrates persuasively that the local government in Southern Song Mingzhou was also far more resourceful and active in promoting local development than previously imagined, providing both financial and organizational support to a wide range of local projects, including those first initiated and advocated by the local elites. Local elite activism was in greater evidence during the Southern Song than earlier, but Lee argues that it was "not the withdrawal of government, but its presence and cooperation with local elites," that made that activism possible (200).

Change, in Lee's eyes, lay more in each dynasty's unique visions and institutional arrangements. Whereas the New Policies advocates during the Northern Song aggressively tried to impose their own blueprint on local society, the Southern Song state viewed itself "not simply [as] its ruler," but "as a participant in and caretaker of local society" (149), more willing to recognize the legitimacy of private interests and more capable of finding ways to accommodate them. Always seeking the "mutual convenience of the public and the private" (gongsi liangbian 公私兩便) (141-44), the Southern Song state was always willing to respond to local demands as they arose. ${ }^{1}$ The Yuan was as different from the Southern Song as it was from the Northern Song. It was in the Yuan that the composition of Mingzhou elites changed most dramatically: the decline of civil service examinations, the growing importance of clerkships, and the expansion of sea transport challenged the status of the established elite families and created new ones (226). It was also in the Yuan that financial support from the government for local projects declined precipitously, while it tied the Song principle of "beneficiary pays"- a principle requiring that local residents who would benefit from a project contribute to its cost-to hereditary occupational household categories and applied it extensively, often leaving local residents responsible for the entire expenditure for maintaining local infrastructure (242). ${ }^{2}$ These differences, in Lee's eyes, were immediate

\footnotetext{
${ }^{1}$ This seems to parallel the contrast between economic reforms of the People's Republic of China in the 1980s and reforms in the 1990s. Huang Yasheng argues that the reforms of the 1980s were experimental and gradualist, featuring the relaxation of existing government constraints on the private sector in order to encourage bottom-up innovations that met indigenous demands, whereas the reforms of the 1990s were characterized by a government bent on carrying out its own technocratic blueprint of economic development. Huang Yasheng, Capitalism with Chinese Characteristics: Entrepreneurship and the State (Cambridge: Cambridge University Press, 2008), 85-104.

${ }^{2}$ Lee traces the "beneficiary pays" principle to the Southern Song. As far as my reading goes, it seems to have become an established practice precisely during the New Policies period. In the edict of 1069 announcing Wang Anshi's new policy on land development and irrigation (nongtian shuili fa 農田水利法), households which would benefit from land reclamation and irrigation projects (shouli renhu 受利人戶) were considered first in line to pay for the expenses, and those short of funds for large-scale projects were expected to "take loans" from the government and wealthy locals. It described the role of government in terms of "regulating" (yueshu 約束) and "organizing" (jiushuai 糾率) when private funds were sufficient, providing financial assistance through loans (bohua jiadai, zhuqi quefa 擘畫假貸, 助其關乏) when private funds were not, managing the funds, and supervising the progress. The same edict also required the circuit intendancies and the prefectural government to coordinate large-scale projects that crossed administrative borders. Cooperation between the
} 
consequences of the unique institutional framework of the Yuan, and none of them were heralds of long-term trends. In other words, Lee sees history as the play-out of a dialectical relationship between continuity and the impact of each dynasty's unique institutional choices (18). For him, every dynasty is a bridge between the preceding and the following periods, but what it inherits and transmits is more complex than any claims of secular trends can adequately capture and always bears the imprint of the dynasty's distinct visions and policies (272).

In the fourth book under discussion, Joseph P. McDermott gives far more weight to long-term social and economic factors in explaining historical change. In his book The Making of a New Rural Order in South China: I. Village, Land, and Lineage in Huizhou, 900-1600, the first of two planned volumes on the social and economic history of Huizhou 徽州 from the Song to the Ming, McDermott crafts a rich narrative of how trust-based lineages came to dominate economic and political resources in the countryside of this important prefecture. In line with the large body of scholarship on lineage development in Fujian and Guangdong, McDermott demonstrates that the earliest Huizhou lineages grew out of the immediate social and political contexts of the early Ming. He shows that local families drew upon widely shared ideas about kinship to organize themselves for the purpose of perpetuating themselves as the natural leaders of their area (235) and fulfilling their military and fiscal obligations to the Ming state (242). Moreover, since Buddhist temples in the early Ming had lost their tax-exempt status (87-89) and were struggling to protect their landholdings from a hostile government (215), lineages not only claimed cultural authority in the statesponsored Neo-Confucian discourse but also appealed to the rich and powerful as an alternative arrangement for sheltering landholdings and evading taxes. ${ }^{3}$ McDermott's book makes a major contribution to this body of scholarship by balancing the attention to immediate institutional contexts and the social and political processes of the early Ming with emphasis on longue-durée factors. He argues that the rise of trust-based lineages was also the result of a successful organizational innovation spurred by long-term economic changes and managerial challenges. The dominant type of large kinship organization until Song times had been the large communal family, which valued "equality and harmony rather than efficiency and productivity" and "paid as much attention to the retention of labor as to the extension of the arable" (114-16). Population growth and resource shortage in Song times rendered this model inadvisable, and Fan Zhongyan's 范仲 淹 (989-1052) idea of establishing a lineage trust was, therefore, a response to the new social and economic conditions. By setting up a corporate estate separate from the private property of individual members of the kinship group and by focusing more on resource management than labor control, Fan's plan provided a loose but fitting framework for his times. Although its organizational structures and practices continued to evolve in subsequent centuries in order to meet the persistent challenges of resource management and membership governance, Fan's plan became the preferred model of large kinship organization in South China from the late twelfth century onward $(114-15,118)$. Such organizations emerged in large numbers in the early Ming. By the midsixteenth century, lineages grew into the dominant village institution in Huizhou and then fell under the sway of an office- or degree-holding gentry, constituting what McDermott calls "a new rural order."

different levels of local government and between the government and local elites surfaces repeatedly in late Northern Song and Southern Song sources. Xu Song 徐松, Song huiyao jigao 宋會要輯稿 (Beijing: Zhonghua shuju, 1957), "Shihuo" 1.27b-28a. The only possible reference to the "beneficiary pays" principle I have seen before the New Policies period was in a memorial from a judicial intendant of Liangzhe in 1045, which proposed that local officials "persuade and induce" (quanyou 勸誘) households which would "benefit from the [increased] rents" (zuli renhu 租利人戶) to fund local irrigation projects on a voluntary basis. See Xu Song, Song huiyao jigao, "Shihuo" 7.12b.

${ }^{3}$ David Faure, Emperor and Ancestor: State and Lineage in South China (Stanford: Stanford University Press, 2007), 73-75. 
The Making of a New Rural Order in South China transcends the age-old paradigm that focuses on the triangular relationship between the state, the gentry, and local society and, like many scholars of the South China school, pays due attention to the development of local institutions. Instead of viewing local institutions as merely a tool of the gentry to solidify their position in local society, it treats the lineage as an independent agent in local history with its own logic of operation, plagued by internal tensions and embedded in a complicated and dynamic relationship with other local forces. Du Zhengzhen's 杜正貞 book Cunshe chuantong yu Ming Qing shishen 村社傳統與明 清士紳 (Village Worship Associations and the Gentry in Ming and Qing Times) takes a similar approach to understanding the evolution of local society in Zezhou 澤州, southern Shanxi, from the Song to the Qing. The gentry and rural organizations constituted two types of authority in local society_-"personal authority" (geren quanwei 個人權威) and "institutional authority" (zhidu quanwei 制度權威)—and had a more "complicated and dynamic" relationship with each other than had been previously recognized. It was their "cooperation and competition and the waxing and waning of their relative strength," Du argues, "that provided one of the agents for change in the power structure of local society" (269). Unlike in Huizhou and South China in general, trust-based lineages never grew into a dominant institution in Zezhou, despite sporadic gentry efforts to promote them. Instead, the principal form of local organization was the village worship association (cunshe 村社), which first appeared in the Northern Song. ${ }^{4}$ Du attributes the formation of these village worship associations to a two-pronged Song strategy of local control that involved extending imperial recognition to local deities, on the one hand, and building an effective rural administrative apparatus, on the other. The effects of these policies were "directly reflected" in the new forms of religious life and social organization in the countryside. Buddhist influences waned, and worship of rain gods began to center on idols sheltered in shrines (280). This change in religious practice brought about a parallel change in the way rural communities were organized. As they pooled resources to construct a common shrine as the site of collective worship, villages entered into an alliance bound by not only geographical proximity but also common religious activities. When these multi-village alliances were first formed, Du argues, their boundaries seem to have been defined by the guan 管, an early Northern Song tax-collecting unit in the countryside. Each multi-village alliance was coextensive with a guan and named itself after the guan. But once there, the multi-village alliance took on a life of its own and continued to define a supra-village rural community centered on its common shrine for many centuries after the guan was abolished as a functional rural administrative unit. This, in turn, strengthened the villagelevel worship associations (she 社), in the form of which each village joined the alliance, so much so that the Jin and Yuan dynasties adopted the village worship association as their basic unit of rural administration (52-56). Du contends that the tenacity of these new forms of rural organizationvillage worship associations and multi-village alliances-was so remarkable that in the following centuries they weathered not only wars and significant changes in the composition of the local population but also the Ming dynasty's attempt to remold them.

For $\mathrm{Du}$, historical change had an origin but was also cumulative. "The emergence of a human settlement is always associated with the birth of a set of local social institutions. Institutional change thenceforth was an ongoing process of accumulation, superposition, transmission, and modification" (279). The village worship association, too, continued to evolve after the Song.

\footnotetext{
${ }^{4}$ The urban and rural formed a continuum in later imperial China and one could easily transform to the other depending on the ebb and flow of local commercial activity. When commercial growth created new market towns in the countryside - as was the case in Guoyu, discussed below-the village worship association was typically carried over as a form of local organization in the new urban neighborhood. I use "village worship association" here as a general term for this type of social organization in both rural and urban contexts for convenience and consistency with McDermott's translation of the she.
} 
And like lineages in South China, its evolution was shaped more by local needs than imperial directives. Du identifies the former half of the Qing as a major moment of change in the history of village worship associations. Over the course of the Ming, economic and cultural developments created new social divisions and deepened existing ones in Zezhou. The growth of commerce and local industry, mainly ironworking and coal mining, gave rise to a powerful merchant class. Wealth, through investment in education, translated into examination success and gentry status. Although literati culture began to take off in Zezhou in the Jin and Yuan, it was only during the 150 years between the Wanli (1573-1620) and Kangxi (1662-1722) reigns that Zezhou men had their day in the civil service examinations (94). The commercial and industrial development also created new towns and a sizable urban population, which complicated the distribution of taxes between townspeople and landowning rural households. It also brought about an influx of immigrants lured by promising job opportunities. The tensions between the gentry and the merchants, villagers and town-dwellers, the rich and the poor, and locals and new immigrants became a vexing problem in some places of Zezhou, only to be exacerbated by the absence of an effective mechanism for promoting social integration (132-45). By the early Qing, the village or town worship association gradually evolved into an institutional space for cooperation and negotiation between diverse interest groups in the local community. Prompted by the need for local defense in the midst of late Ming chaos, many village worship associations transcended their traditional roles in the religious realm and took on a broader range of public responsibilities. Their authority and sphere of activity continued to expand in the first half of the Qing, gradually evolving into a self-governing institution in rural society. As the official apparatus of rural control and resource extraction hollowed out over the course of the Qing and the influence of the gentry declined after the mid-eighteenth century as a result of poor examination performance, village worship associations expanded to meet the local needs for a public authority that could provide community services, enforce social regulation, organize economic activities, and ease the process of fulfilling the taxpaying households' fiscal obligations to the state $(214,217-22)$.

These five books have many features in common. They all take a longue-durée perspective. They all seek to understand how the relationship between the state, the elite, and local society evolved over time. Above all, they all point, in one way or another, to the Song dynasty as a watershed. Tackett implies that the Song ushered in a new age, being the first major dynasty after the demise of the "medieval Chinese aristocracy." Iiyama argues that it was the Southern Song that first diverged from China's millennium-old political traditions by acknowledging the literati's leadership in local society and thereby initiating new dynamics between state and society that were inherited by the Ming-Qing period. For McDermott, the Song was a period when the economy finally developed to the point that made the large communal family an unappealing model of large kinship organization, thus giving rise to an institutional innovation-the corporate, or trust-based, lineage - that eventually became the dominant village institution in the South China countryside a few centuries later. In Du's study, the dominant form of rural organization was the village worship association, which, too, had its origin in the Northern Song policies of rural administration and the new forms of religious life. Yet both McDermott and Du also stress the continuous evolution of these institutions in Ming and Qing times. Lee is perhaps the most cautious. Lee points out that it was in the Southern Song that the state ceased to impose its own vision on local society, but instead sought cooperation with the local elite, which now included a quickly expanding and increasingly assertive literati population. He nevertheless stresses the uniqueness of each dynasty and seems hesitant to attach any greater importance to the changes he observes in the Song than those in other periods.

The five books raise several related questions: How should we understand continuity and change in Chinese history? Was there a pattern or trend, and what position did the Song have in it? To put it in a slightly different way, did changes that transpired in the Song signal a major divide between 
two distinctive historical periods, or were they nothing special since—as it was for Heraclitus_-all was flux?

\section{THE "LOCALIST TURN" AND THE RISE OF THE GENTRY}

The view of the Song as a turning point in history has an intellectual lineage that goes back to Naitō Konan 內藤湖南 (1866-1934). In his view, the Song marked the beginning of the rise of imperial autocracy, a trend which culminated in the Ming-Qing period. Following the demise of the aristocracy during the late Tang and the Five Dynasties, he argued, the principle of bureaucratic recruitment shifted from "an independent birthright" beyond the emperor's control to "a conditional appointment by imperial will." Whereas the Tang emperor was only a representative of the aristocracy whose power was constrained by aristocratic interests, the emperor from the Song onward exercised absolute power over his officials, whom he himself recruited from the commoners through civil service examinations. Naito pointed out emphatically the many changes in formal governmental organizations and the dynamics of court politics that led to an "increasing arrogation of state functions in the emperor's hands and a corresponding elevation of his ritual status." 5

In the 1980s, social historians proposed a competing view. They shifted attention from politics and institutions to the behavioral patterns of the elite and from distribution of power within the government to the relationship between state and local society. The most important proponents of this view include Robert M. Hartwell and his student Robert P. Hymes. In his pioneering article "Demographic, Political, and Social Transformations of China, 750-1550," Hartwell gave less weight to changes between the Tang and Song than between the two halves of the Song dynasty itself. ${ }^{6} \mathrm{He}$ described the change as "the demise of a semi-hereditary professional bureaucratic elite... [in the early twelfth century] and its replacement... by a multitude of local elite gentry families." Whereas the local elite based its power in local society and "viewed a bureaucratic career as only one of a variety of occupational choices," the professional elite, argued Hartwell, specialized in government service and perpetuated itself in high offices over multiple generations. ${ }^{7}$ Hartwell defined the professional elite by its distinctive social behavior, which in many ways resembles that of the ninth-century Tang elite in Tackett's study: its members claimed descent from the great aristocratic clans, established their main residence in the capital region, intermarried with each other regardless of regional origin, and served in high offices generation after generation. It should be noted, however, that the professional elite identified by Hartwell was composed of a fairly limited number of families in the Song which dominated, but did not monopolize, the Song government. Although it provided a "disproportionate number of incumbents" to high offices in the Song government, it never monopolized government offices to the extent that the ninth-century elite did. At all times and at all levels of government, it shared political power with men from local elite families. Even at the peak of its power, for example, it claimed less than one-third of policy-making offices while the local elite families always staffed at least half of these positions. ${ }^{8}$

\footnotetext{
${ }^{5}$ William Rowe, "Approaches to Modern Chinese Social History," in Reliving the Past: The Worlds of Social History, edited by Olivier Zunz (Chapel Hill: University of North Carolina Press, 1985), 261; Naitō Torajirō 內藤虎次郎, “Gaikakuteki Tō-Sō jidaikan” 概括的唐宋時代觀, Rekishi to chiri 歴史と地理 9.5 (1922), 1-12.

${ }^{6}$ Patricia Ebrey, "The Dynamics of Elite Domination in Sung China," Harvard Journal of Asiatic Studies 48.2 (1988), 495.

${ }^{7}$ Robert M. Hartwell, "Demographic, Political, and Social Transformations of China, 750-1550," Harvard Journal of Asiatic Studies 42.2 (1982), 366, 425-26.

${ }^{8}$ Hartwell, "Demographic, Political, and Social Transformations of China," 409.
} 
Hartwell's study broke new ground by defining the ruling elite as much by its social behavior as by its claims of ancestry. It is his student, Robert P. Hymes, who has applied this approach fully. In an influential study published four years later, Hymes shifts attention from incumbents of national offices to those men and women who had privileged "access to wealth, power, and prestige... in the local scheme of things" in Fuzhou 撫州, Jiangxi, and combines prosopographical research on their residence and marriage patterns with close analyses of their activities in local society. ${ }^{9}$ He notes that the social behavior associated with the professional elite-capital residence, intermarriage with each other regardless of regional origin, and self-perpetuation in government - was characteristic of a much larger number of families than Hartwell had realized, including many from Fuzhou whom Hartwell would have categorized as the "local elite gentry families." This behavior disappeared, however, in the Southern Song. Therefore, Hymes argues, the transition in the early twelfth century should be best described not as the demise of a specific status group but, instead, the abandonment of one strategy in favor of another. Whereas local elite families in the Northern Song pursued a "national" or "bureaucratic" strategy centered on the attainment of high office, elite families in Southern Song Fuzhou followed a "localist" strategy that concentrated on consolidating their local power base and sought only occasional office as one element of perpetuating their local status. Hymes's evidence comes, like that of Hartwell, from their subjects' contrasting decisions on residence and marriage. In pursuit of high office, Fuzhou men in the Northern Song who succeeded in the examinations and received an appointment in government usually migrated from Fuzhou to major economic and political centers and contracted "longdistance" marriages with families from other counties and prefectures. Only those who had not yet achieved office stayed in Fuzhou, but they too, Hymes suspects, shared the same ultimate goal of rising to political prominence and their efforts at home-accumulating wealth and building connections-was the first step in that direction. ${ }^{10}$ This all changed in the Southern Song. Elite families in Southern Song Fuzhou focused more on consolidating their status at home than on rising high in government. Not a single prominent family left Fuzhou after 1127. They sought affines almost exclusively from Fuzhou itself and, most often, from just within their home counties. They engaged actively in organizing local defense, developing infrastructure, promoting local welfare, and constructing local cultural spaces. They developed a strong local consciousness, employing history-writing to carve out an identity for their home locales and for themselves as local men. The Southern Song, therefore, saw "the growing importance of locality in elite social life and self-conceptions" and the separation of elite from state. ${ }^{11}$

Sukhee Lee questions this argument. His study reveals remarkable continuity, not change, in the patterns of elite marriage between the two halves of the Song. He contends that elite families in both Northern and Southern Song Mingzhou arranged a mix of local and non-local marriages. In both periods, Lee shows, approximately half of the elite marriages were between families from the same county while a third were across prefectural borders (64-65). In a review of Hymes's evidence, he points out further that the high incidence of localized marriages in Fuzhou reflects, at best, the tendency in the last decades of the Southern Song or, at worst, perhaps a bias in the sources we have for those years (80-82). These findings are consistent with earlier studies on elite marriage inspired by Hymes. Beverly J. Bossler's study on grand councilor families and the Wuzhou 柔州 (now Jinhua, Zhejiang) elite, for example, also reveals more continuity than change between the two halves of

\footnotetext{
${ }^{9}$ Robert P. Hymes, Statesmen and Gentlemen: The Elite of Fu-chou, Chiang-hsi, in Northern and Southern Sung (Cambridge: Cambridge University Press, 1986), 7.

${ }^{10}$ Hymes, Statesmen and Gentlemen, 119-20.

${ }^{11}$ Peter K. Bol, “The 'Localist Turn' and 'Local Identity' in Later Imperial China,” Late Imperial China 24.2 (2003), 1-50. Peter K. Bol, "The Rise of Local History: History, Geography, and Culture in Southern Song and Yuan Wuzhou," Harvard Journal of Asiatic Studies 61.1 (2001), 37-76.
} 
the Song, leading her to argue that that the geography of marriage was primarily a function of political status, with higher-ranking officials in both periods more likely to have affines from outside their home counties and prefectures than their lower-ranking colleagues. The relatively higher incidence of local marriage in Southern Song Wuzhou was almost certainly the result of more marriages of commoners being documented in this period. She also stresses the strong preference in both periods for finding affines nearby, noting that grand councilor families in the Northern Song who contracted marriages with each other, in fact, lived mostly in the capital region and that Wuzhou elite families who went beyond prefectural borders for in-laws usually married southerners from not-too-distant regions. ${ }^{12}$ The apparent contrast between Northern and Southern Song geography of marriage, therefore, was a product of confusion of ancestral homes with places of actual residence and historiographical biases. Likewise, in a study of southern Fujian, Hugh Clark argues that marriage was "at all times first and foremost a local affair," though elites in both the Northern and Southern Song also regularly had affines from outside their home prefectures. ${ }^{13}$

We should exercise caution, however, before rejecting the "localist turn" paradigm too quickly. Read against Tackett's book on the Tang political elite, Lee's study on Mingzhou brings to the fore the dramatic change between the late Tang and the Southern Song. As late as the waning decades of the Tang, offices at all levels of government continued to be monopolized by a capital elite. Political prominence was so closely related to capital residence that relocation to the provinces was nothing short of a death knell for a family's political future. This contrasts starkly with the Southern Song. For Mingzhou men in the Southern Song, living outside the capital was no obstacle to political success. Many local families, like the Lous 樓 and Shis 史, rose to national eminence and perpetuated their status until the end of the Song. Rather than discrediting the "localist turn" paradigm, Lee's study, I think, challenges us to reconsider and better articulate what it meant, when and why it happened, and what the implications were.

First of all, underlying this persistent scholarly interest in the geography of marriage is the assumption we have inherited from Hartwell that the choice of affines, along with decisions on migration, gives a clue to understanding the character of the ruling elite-whether it constituted a distinct, self-perpetuating status group separate from the layer of wealthy, powerful families which assumed leadership in local society - and how it maintained its political status. To take this assumption seriously means that whether or not families without official rank married locally, therefore, is irrelevant. ${ }^{14}$ It also means that marriage patterns of the officeholding elite must be interpreted in tandem with other aspects of its social behavior (such as its residence patterns) as a measure of its social distinctiveness and the degree of its attachment to local communities whence they hailed. Second, as social historians looking for long-term trends often remind us, major institutional changes in history, not to mention social and economic changes, do not always coincide with the rise and fall of dynasties, and relying on major dynastic markers-such as the

\footnotetext{
${ }^{12}$ Beverly Bossler, Powerful Relations: Kinship, Status, and the State in Sung China (960-1279) (Cambridge, Mass.: Harvard University Asia Center, 1998), 164-65.

${ }^{13}$ Hugh Clark, Portrait of a Community: Society, Culture, and the Structures of Kinship in the Mulan River Valley (Fujian) from the Late Tang through the Song (Hong Kong: Chinese University Press, 2007), 165.

${ }^{14}$ In fact, all scholars agree that non-officeholding families had little choice but to marry locally. Bossler, Powerful Relations, 165; Hymes, Statesmen and Gentlemen, 120. Likewise, marriages arranged by families before they produced officials were more likely to be local than after they acquired their official status. Lee's study shows that even the famed Shis married locally in the Northern Song prior to their political ascendancy. Lee, Negotiated Power, 65; Song Chen, "Bunken tōchika ni okeru zaichi shakai to kōiki chihō: Sōdai Shisen o chūshin toshite” 分権統治下における在地社会と広域地方一宋代四川を中心として一, in Chūgoku Sōdai no chiiki zō: Hikakushi kara mita sensei kokka to chiiki 中国宋代の地域像一比較史から みた専制国家と地域, edited by Ihara Hiroshi 伊原弘, et al. (Tokyo: Iwata-shoin, 2013), 159-61.
} 


\section{Song Chen}

founding of the Northern Song in 960 and the Jurchen conquest of 1127-to define our unit of analysis runs the risk of obscuring important changes. Once we are more precise on defining periods of comparison, focus exclusively on the officeholding elite, interpret its choice of affines alongside its patterns of residence, all evidence points to the mid-eleventh century — not the late Tang or the end of the Northern Song - as a major watershed in history.

Relocation to the capital and the Grand Canal region (an economic hub that provided convenient access to the capital) was a popular choice for many who became officials very early in the Song dynasty, not just those who rose to high ranks, but it began to lose its appeal around the middle of the eleventh century. All six emigrant families from Fuzhou identified by Hymes, for example, produced their first metropolitan degree holder (jinshi) by 1015. These six families, plus the Xus 胥, of whom we know little, accounted for the vast majority of degree holders from Fuzhou before 1040. Four of them established new gravesites in the vicinity of the capital or along the Grand Canal by the early eleventh century, almost immediately following their examination success. ${ }^{15}$ By contrast, while a far greater number of Fuzhou men from a much larger pool of local families passed the examinations between 1040 and 1127, there is no evidence that any of these newly successful individuals, except Cai Chengxi 蔡承禧, relocated from their home prefecture. ${ }^{16}$ Wuzhou and Mingzhou records reveal a similar trend. Hu Ze 胡則 (963-1039), jinshi of 989 (and, in fact, the only degree holder of Wuzhou before 1040 for whom detailed biographical data survives), established a residence in Kaifeng shortly after receiving his degree and moved to Hangzhou at the southern end of the Grand Canal upon retirement. ${ }^{17}$ Wuzhou began to produce jinshi with considerable regularity after 1040, but judging from late Northern and early Southern Song sources, nobody but the

${ }^{15}$ Hymes, Statesmen and Gentlemen, 310-12. These four include the Yues 樂, the Yans 晏, two branches of the Wangs 王, and one branch of the Wus 吳. Yan Shu 晏殊 (991-1055) passed the examinations in 1005 and was buried in Xuzhou 許州. Wang Guanzhi王貫之 (967-1028) obtained the jinshi degree in 1000 and was initially buried in Hezhou 和州. His grave was later moved to neighboring Zhenzhou 真州, closer to the Grand Canal, following the death of his widow. Wang Yongzhi 用之, brother of Guanzhi and grandfather of Wang Anshi, did not obtain official ranks and stayed in Fuzhou. But Yongzhi's son Yi 益 (993-1038) passed the examinations in 1015 and established a new home in Jiangning 江寧. Yue Shi 樂史 (930-1007) passed the examinations in 980. No evidence of his burial site survives, but the family moved to Luoyang by at least his son's generation before 1039. See Wang Anshi, Linchuan xiansheng wenji 臨川先生文集 (Sibu congkan edition), 99.9b (寧國縣太君樂氏墓誌銘), also included in Quan Song wen 全宋文 (Shanghai: Shanghai cishu chubanshe, 2007), 65:1419.234. Yin Zhu 尹洙, Henan xiansheng wenji 河南先生文集 (Sibu congkan edition), 15.6b-7a (故夫人黃氏墓誌銘, also in Quan Song wen, 28:589.89). Wu Min 吳敏 passed the examinations in 992. One of his sons, Wu Ben 吳賁, entered government service using the yin privilege and moved to Tangzhou 唐州. Another son of Min, Wu Fan 吳蕃, and his descendants were politically obscure and did not seem to move from Fuzhou until around 1080. Fan did not obtain any official rank and his son Ze 賾 had only a minor office. Ze's son, Que 㷫 (1063-1144), however, relocated to Jiangning during the Yuanfeng period (1078-85) to join his affinal kin, the Wangs, and received an office with Wang Anshi's posthumous grace. Sun Di 孫覿, Hongqing jushi wenji 䲨慶居士文集 (Siku quanshu edition), 34.16b-20a (宋故右 承議郎吳公墓誌銘, also in Quan Song wen, 161:3488.8).

Of the remaining two emigrant families, the Zengs 曾 made a uniquely heroic effort to maintain their gravesite in Fuzhou, but their primary geographic attachment seems to have long been elsewhere. The family produced their first Song official when Zeng Zhiyao 曾致堯 (947-1012) passed the examinations in 983. And since 975 every generation of the Zengs married regularly with families living in the capital region or along the Grand Canal. Although Zeng Zhao 曾肇 (1047-1107) insisted on being carried back to Fuzhou for burial, he and his brother $\mathrm{Bu}$ 布 (1036-1107) maintained their main residence in Runzhou 潤州. Only the Cais 蔡 seem to be an exception, relocating from Fuzhou only after Chengxi 承禧 (1035-1084) passed the examinations in 1057.

${ }^{16}$ Fuzhou fuzhi 撫州府志 (1876 edition, reprinted in Zhongguo fangzhi congshu), 42.1a-8b.

${ }^{17}$ Bossler, Powerful Relations, 97. 
famous general Zong Ze 宗澤 (1059-1128) seems to have moved out. ${ }^{18}$ Unfortunately, Sukhee Lee provides no account of elite migration in his book. But as far as my own reading goes, elite families in Mingzhou made similar decisions on residence. All three families一the Wangs 王, the Ges 葛, and the Shens 沈一who relocated from Mingzhou entered office before $1030 .{ }^{19}$ By contrast, there is no evidence that any of the Mingzhou men who passed the examinations after 1040 abandoned their ancestral homes. ${ }^{20}$ In Sichuan, too, nearly all those who relocated to the capital and the Grand Canal region entered civil service before 1040, while all but one of the officials who received the jinshi between 1060 and 1127 abandoned their homes in Sichuan. ${ }^{21}$ The same trend is also visible among men occupying the top positions in the Song government. Beverly Bossler has noted that grand councilor families found the appeal of Kaifeng declining by the mid-eleventh century. A total of twenty-eight grand councilors in the Northern Song were raised outside the capital region. Fifteen of them came into office before 1050 (indicating that they first obtained an official rank sometime before 1030 at the latest), of whom all but one

\footnotetext{
${ }^{18}$ Bossler, Powerful Relations, 132.

${ }^{19}$ Wang Wenliang 王文亮, who held a prefectural office in Wuyue, submitted to Song rule and was buried in Jiangling by his son Zhou in 1051 many years after his death. His grandson Guai 夹 was officially registered (guan 貫) as a Hezhou 和州 resident in the examination list of 1070. Wang Anshi, Linchuan xiansheng wenji, 95.7b (贈尚書刑部侍郎王公墓誌銘 [王文亮], also in Quan Song wen, 65:1416.179). Baoqing Siming zhi 寶 慶四明志 (1227, reprinted in Song Yuan fangzhi congkan 宋元方志叢刊 [Beijing: Zhonghua shuju, 1990]), 10.3a. The Ges 暮 moved most frequently in the first two generations under the Song. Ge Yuan 葛源 (9831054) was born in Chuzhou 處州 and moved to Mingzhou. He passed the examinations in 1012 and was buried in Runzhou. His son Liangsi 良嗣 (1013-65) was also buried there, despite his official registration as a Kaifeng resident in the examination list of 1051. Wang Anshi, Linchuan xiansheng wenji, 96.12a (度支郎 中葛公墓誌銘 [葛源], also in Quan Song wen, 65:1417.197); 92.11a (葛興祖墓誌銘 [葛良嗣], also in Quan Song wen, 65:1413.145); Baoqing Siming zhi, 10.1b-2b. Shen Jian 沈兼 (974-1046) made five unsuccessful attempts at the examinations and was rewarded with a degree only in 1024 at the age of fifty. His last office was in Suzhou 蘇州, where his son maintained a residence and a gravesite. Wang Anshi, Linchuan xiansheng wenji, 92.8a (太子中舍沈君墓誌銘 [沈兼], also in Quan Song wen, 65:1413.142); Qiandao Siming tujing 乾道四明圖經 (1169, reprinted in Song Yuan fangzhi congkan), 12.4982; Shen Kua 沈括, Changxing $j i$ 長興集 (Sibu congkan edition), 30.6b (故天章閣待制沈興宗墓誌銘 [沈起], also in Quan Song wen, 78:1696.51). His son Qi 起 passed the examinations in 1042. Baoqing Siming zhi, 10.2a.

${ }^{20}$ Feng Ji 豐稷 (1033-1107), jinshi of 1059, for example, was buried in his native county in Mingzhou. Chen Guan 陳瓘, Feng Qingmin gong yishu 豐清敏公遺書 (Siming congshu 四明叢書 edition), fulu 附 錄.3a (宋禮部尚書敘復朝請郎提舉毫州太清宮豐公墓誌). The Zhous 周 produced their first jinshi in the Qingli reign period (1041-48). The success was continued in the next generation with the examination success of Chuhou 處厚 and Shihou 師厚, jinshi of 1046 and 1053 respectively. Little is known of Chuhou, but Shihou continued to maintain his home in Mingzhou and was buried there. His descendants continued to show up in local sources well into the mid-thirteenth century. His widow died in her private residence in Mingzhou in 1109 and was buried in her husband's gravesite there. Zou Hao 鄒浩, Daoxiang ji 道鄉集 (SKQS edition), 37.13b (高平縣太君范氏墓誌銘 [范仲温女、周師厚妻], also in Quan Song wen, 132:2847.73); Baoqing Siming zhi, 10.2b; Lou Yue 樓錀, Gong kui ji 攻媿集 (Sibu congkan edition), 109.1a (周伯範墓誌 銘[周模]). The last Zhou man to appear in the examination list of the local gazetteer was Zhou Tan 周坦, jinshi of 1250, a fifth-generation descendant of Shihou. Baoqing Siming zhi, 10.20b. Zhou Zhu 周銖, one of two Shihou's sons, was officially registered as a Huzhou 湖州 resident, but there is evidence that he continued to live in Mingzhou after retirement from a very brief career in government. See Baoqing Siming zhi, 10.4b, and Lou Yue, Gong kui ji, 103.20a (周伯濟墓誌銘 [周楫]).

${ }^{21}$ Song Chen, "Managing the Territories from Afar: The Imperial State and Elites in Sichuan, 755-1279" (PhD diss., Harvard University, 2011), 253. Of the nine officials who entered civil service between 1040 and 1059 and relocated from Sichuan, five established their new residences in places other than the capital and the Grand Canal.
} 
relocated to Kaifeng; thirteen came into office after 1050, of whom only one moved to the capital and two others, by my own count, migrated to the Grand Canal region. ${ }^{22}$

The geography of marriage cannot be understood separately from changing patterns of residence. Choosing an affine from outside one's native area had different social meanings for a family which continued to live in its native place and a family which did not. Marriages uniting families from different native places in the Northern Song often involved emigrant officeholders on one or both sides, and the actual residences of the two families in a marriage were usually in close proximity. These marriages, therefore, indicate the emigrants' weakening ties with their native places and their effort to integrate into the capital-oriented elite circle they had moved into. Hymes has observed thirty-nine marriages between families from Fuzhou and those from outside the prefecture, all but five of which were arranged by the six emigrant families. ${ }^{23}$ Of these thirty-four marriages, only five were with families from other Jiangxi prefectures (nos. 3, 4, 26, 30, 35 in Hymes's list), while at least twenty-one of them (nos. 5, 6, 8-12, 14, 16-20, $23-25,28,29,31,33,36$ ) were with officeholding families who lived in fairly close range of where the Fuzhou men had moved (or would have eventually moved). ${ }^{24}$ The Wangs and

\footnotetext{
${ }^{22}$ Bossler, Powerful Relations, 46. Of the three grand councilors who came into office after 1050 and decided to relocate from their native places, two of them, again, received their jinshi degree before 1030, and the third (Zeng $\mathrm{Bu}$ ) in 1057. Bossler does not specify whom the grand councilor was that came into office after 1050 and moved to the Kaifeng area. She seems to refer to Zeng Gongliang 曾公亮 (999-1078), nominally from Fujian but buried in Xinzheng 新鄭 county of Kaifeng. I suspect, however, that the family may have established this gravesite in an earlier generation. Gongliang's grandfather served the Min state and submitted to the Song rule. His father ranked second in the examinations in 989 and served in court offices. At the very least, Gongliang's brother Gongwang 公望 (1010-1066) had been buried in Xinzheng county before Gongliang's death. Zeng Zhao 曾肇, “Zeng taishi Gongliang xingzhuang” 曾太師公亮行狀, in Mingchen beizhuan wanyan zhi ji 名臣碑傳琬琰之集, edited by Du Dagui 杜大珪 (Siku quanshu edition), 52.1a; also in Quan Song wen, 110:2382.99; Qiang Zhi 強至, Cibu ji 祠部集 (Siku quanshu edition), 35.9b (朝奉郎守尚書虞部郎中上輕車都尉賜緋魚袋曾府君墓誌銘 [曾公望], also in Quan Song wen, 67:1455.176). Besides, Pang Ji 龐籍 (988-1063), appointed grand councilor in 1051 and buried in Kaifeng, may be another case of relocation to Kaifeng. But he hailed from a place (Shanzhou 單州) already very close to the capital. Wang Gui 王珪, Huayang ji 華陽集 (SKQS edition), 48.1a (推誠保德翊戴功臣開 府儀同三司太子太保致仕上柱國穎國公食邑八千四百户食實封二千一百户贈司空兼侍中龐公神道碑 銘 [龐籍], also in Quan Song wen, 53:1155.205). The two grand councilors who moved to the Grand Canal region were Chen Shengzhi 陳升之 (1011-79) of Fujian and Zeng Bu of Jiangxi, both of whom moved to Runzhou. Zeng Gongliang received his jinshi degree in 1024, Pang in 1015, Chen in the Jingyou reign period (1034-38), and Zeng Bu in 1057.

${ }^{23}$ Hymes, Statesmen and Gentlemen, 87.

${ }^{24}$ Hymes, Statement and Gentlemen, 84-86. In both his discussion and Map 7, Hymes reports a notable number of marriages between Fuzhou emigrants and families who were not from Jiangxi, the capital region, or the Grand Canal area. But he seems to have been misled by the nominal places of origin provided in his sources. Wu Anchi (no. 20) was nominally from Fujian, but his grandfather was buried in Zhengzhou. Ouyang Xiu 歐陽修, Ouyang wenzhonggong ji 歐陽文忠公集 (Sibu congkan edition), 32.5b-10b (資政殿 大學士尚書左丞贈吏部尚書正肅吳公墓誌銘 [吳育], also in Quan Song wen, 35:753.349). Lady Chao 昆 (no. 12) was nominally from Kaifeng, but her father Zongke 宗恪 (1007-69) was buried in Yangzhou 揚 州. Zeng Gong 曾鞏, Yuanfeng leigao 元豐類藻, 46.7a (光祿少卿昆公墓誌銘 [昆宗恪], also in Quan Song wen, 58:1270.276). Lady Su 蘇 (no. 14) was nominally from Meizhou 眉州, Sichuan, but her father Zhe 轍 (1039-1112) relocated to Ruzhou 汝州, bordering Luoyang and close to Kaifeng, and the marriage was arranged in the capital. Zeng Xie 曾協, Yunzhuang ji 雲莊集, 5.29a-32a (代從兄作伯母事述, also in Quan Song wen, 219:4854.80). Others settled in Jiangxi and its vicinity. Lady Li (no. 35) was nominally from Fujian, but her grandfather Yin 寅 had moved to Hongzhou 洪州, Jiangxi, following a brief detention at Kaifeng upon the Song conquest. Wang Anshi, Linchuan xiansheng wenji, 88.8b (虞部郎中贈衛尉卿李 公神道碑 [李虛舟], also in Quan Song wen, 65:1411.102); Tuotuo 脫脫, Song shi 宋史, 300.9973. Zhang
} 
Zengs, for instance, sought affines predominantly from along the Grand Canal, and the Les and the Yans from the capital region. Many of these families, such as Wu Anchi 吳安持 of Zhengzhou 鄭州 and the Zhous of Taizhou 泰州, were themselves early Song immigrants to the capital and the Grand Canal regions. This behavior, therefore, reveals a strong tendency before the mid-eleventh century for officeholding families of different regional origins to form a distinct status group centered on the Song capital and Grand Canal regions and separate from native communities of each individual family. It is a sign of the political elite's capital orientation and its separation from the leadership of local society. It reveals a close relationship between political success and capital-oriented social networks, highly reminiscent of the late Tang elite discussed in Tackett's study.

By contrast, Wuzhou and Mingzhou records are notably scarce on the early Song. ${ }^{25}$ Evidence of elite marriages in both prefectures comes almost exclusively from after the mid-eleventh century, when most officeholding families_-including politically prominent lineages like the Lous and Shis - decided against relocation. Marriages across prefectural boundaries in these cases, therefore, took on a different social meaning. They did not weaken the elite's ties to its native places; rather, they strengthened its local position by extending its social networks beyond its home prefectures. These networks, in fact, centered on the elite's native places. Wuzhou people who chose affines from outside the prefecture nevertheless tended to marry southerners from not-too-distant places (164-65). In the same vein, the vast majority of marriages in Southern Song and Yuan Mingzhou were within the prefectural borders. Of the eighty-five marriages in the Southern Song that were not, seventy were inside the two circuits of Liangzhe 兩浙; of the sixteen such marriages in the Yuan, fourteen were inside Liangzhe (Lee, 281-306, Appendix 2). What Beverly Bossler has aptly observed in the marriage patterns of grand councilor families, I think, applies to the Song political elite in general, except that the change already began to surface around the mideleventh century, a few decades earlier than the fall of the Northern Song. In the Northern Song, she says, "the network appears to have had a single center, a single point of convergence in the capital," while in the Southern Song "that center had disappeared, and the network had instead numerous regional nodes." 26

Thus, the elite behavior Lee observes in Mingzhou, for both the Northern and Southern Song, concerns mostly the period after the "localist turn" had already taken place around the mid-eleventh century. Read together with Tackett's book, it actually underscores the dramatic change between the late Tang and Song: that the political elite ceased to exist as a distinct status group centered on the capital after the mid-eleventh century but became more embedded in the local society from which it had come. ${ }^{27}$ This change seems to have lasting significance. The close relationship

Kui 張奎 (no. 22), nominally of Fujian, was buried in Jiangzhou 江州 at the junction of the Gan River and Yangzi River. Wang Anshi, Linchuan xiansheng wenji, 99.5b (長安縣太君王氏墓誌 [王益女、張奎妻], also in Quan Song wen, 65:1419.229). No. 30 was a typo: Li Xiuyong 李修永 was from Hongzhou, Jiangxi, not Huangzhou 黃州, Hubei. Lü Nangong 呂南公, Guanyuan ji 灌園集 (Siku quanshu edition), 19.10a (宋故撫州臨川縣丞李君墓誌銘 [李元], also in Quan Song wen, 109:2374.338). In the remaining seven cases (nos. 7, 13, 21, 32, 34, 37, 39), the place of origin given for the affines of Fuzhou emigrants might also be nominal, but with the exception of Jiang Bao 江褒 (no. 7), there is no information on their actual residence or their family's burial site. Jiang Bao 江褒, nominally of Chuzhou 處州, was buried in Huzhou 湖州, close to the Grand Canal. Cheng Ju 程俱, Beishan ji 北山集 (Sibu congkan edition), 31.3a (承議郎信安江君墓誌銘 [江衰], also in Quan Song wen, 155:3343.397); Beishan ji, 31.13b (宋奉議郎孺 人曾氏墓誌銘 [曾布女], also in Quan Song wen, 155:3343.405).

${ }^{25}$ Bossler, Powerful Relations, 130; Lee, Negotiated Power, 26.

${ }^{26}$ Bossler, Powerful Relations, 93.

${ }^{27}$ Beverly Bossler has made a similar observation in her study of the grand councilors. "Whereas in the Northern Sung [Song] the highest level of the political elite was effectively skimmed off the top of local society and concentrated in the capital," she argues, "in the Southern Sung that political elite remained much 


\section{Song Chen}

between the officeholding elite and its native places continued to be a prominent feature of the Ming and Qing.

Why then did the capital lose its appeal? One line of explanation blames power struggles and the Jurchen invasion for making bureaucratic careers less desirable. Power struggles in the late eleventh century, it is argued, turned court politics into dangerous waters and added to the uncertainty of obtaining high office, while constant military threat from the Jurchens after 1125 tightened Song finances and limited its fields of action, making influence over central decisions "less relevant to an elite family's day-to-day life." ${ }^{28}$ This line of argument faces several difficulties. It does not explain, for example, why the late Tang elite actively pursued high office and had impressive success in monopolizing political power and perpetuating its status, despite the nefarious struggles that plagued the ninth-century court. Neither does it explain why relocation to the capital seems to have started to lose its appeal, in fact, well before the late Northern Song factional strife and the fall of the capital. More importantly, if the localist turn around the mid-eleventh century signals the beginning of a long-term trend that continued into the Ming-Qing period, it also requires a long-term explanation for why the tide was not reversed in subsequent dynasties - an explanation that short-term events are not likely to provide.

Conversely, the dazzling political success of Southern Song Mingzhou men, like that of the Shis, lends support to the alternative explanation that by the mid-eleventh century capital residence and capital-centered networks were no longer as important for achieving political prominence as they had been in the late Tang. As Bossler observes of the Song grand councilors, "it was not so much that people had lost interest in office, but that the political and social advantages once exclusive to the center had become much more widely diffused." 29 The institution of civil service examinations as the major route to office, the expansion of quotas for prefectural examination graduates in the south, the flourishing of print culture, and the proliferation of public and private schools outside the capital in the eleventh century ended the capital's monopoly over political opportunity, making it ever more possible to translate wealth into political status via investment in education. Over time, access to the fruits of economic prosperity seems to have become more important than access to the capital for achieving political success. ${ }^{30}$ Southern examination success certainly made connections increasingly available to those outside the capital, but probably more decisive was the institution of anonymity in the examinations and the explicit prohibition of "circulating scrolls" (xingjuan 行卷), which reduced the importance of having connections. ${ }^{31}$

The general trend from the ninth century on, therefore, was the expanding scope of political participation outside the narrow circle of a capital elite, eventually giving rise to an officeholding elite in local society which attained political prominence while remaining very much part of their local communities. The civil service examination system played a pivotal role in this change, and it also had a strong spillover effect. By recruiting a few hundred scholars into the civil service every three years, it encouraged many more to emulate them, bringing about in local society a literati population (shi 士) many times larger than the officeholding elite, who participated in a national culture

more part of the local society from which it had come." This observation, I think, applies not only to the "highest level of the political elite," but to the political elite before the mid-eleventh century in general. Bossler, Powerful Relations, 94.

${ }^{28}$ Hartwell, "Demographic, Political, and Social Transformations of China," 422; Hymes, Statesmen and Gentlemen, 121-22, 217.

${ }^{29}$ Bossler, Powerful Relations, 48.

${ }^{30}$ Song Chen, "Governing a Multicentered Empire: Prefects and Their Networks in the 1040s and 1210s," in State Power in China, 900-1325, edited by Patricia Buckley Ebrey and Paul Jakov Smith (Seattle: University of Washington Press, 2016), 101-52.

${ }^{31}$ John W. Chaffee, The Thorny Gates of Learning in Sung China (Albany: State University of New York Press, 1995), 51. 
and prided themselves on their learning. Their status as the $s h i$ was certified through enrollment in government schools and participation in the examinations. ${ }^{32}$ These men, with their official rank and educational qualifications, constituted a new stratum of local elite-the "gentry" (jinshen 縉紳) or "literati-officials" (shidafu 士大夫). Their offices, degrees, and studentships brought not only social prestige, but also substantial fiscal and legal privileges. ${ }^{33}$ These privileges functioned as new markers of social standing in local society which rivaled the importance of wealth and history of local residence. The Mingzhou literati-official Lou Yue 樓錀 (1137-1213), for example, took pride in his hometown for according respect on the basis of a person's seniority instead of his official rank. "Good feelings among fellow residents are so highly valued," he remarked, "that a man is always ranked on the basis of his age, be he a commoner or a member of the officeholding gentry” 鄉誼最重, 薦紳韋布, 序必以齒 (Lee, 151 [translation modified]). This remark invites many possible readings. It implies that elsewhere, in Lou's times, official rank probably trumped time-honored local traditions that had valued seniority. With a slight stretch of the imagination, one may also take it to mean that a similar effort to give greater weight to official rank than age was likewise attempted in Mingzhou but successfully resisted in order not to hurt the "good feelings among fellow residents." However one reads Lou's remarks, it is clear that these new markers of social standing threatened to disrupt age-old practices in deciding the pecking-order distinctions in local society. The relative importance of different kinds of status markers was probably constantly contested in local society. One need only compare the organizing principles of the "Genealogies of Chengdu Clans" (Chengdu shizu pu 成都氏族譜), compiled in the late 1190s, and a similar composite genealogy of the Huizhou clans compiled in the sixteenth century. The former lists only local families with unbroken traditions of civil service under the Song, groups them first by the county where they resided, and then within each group arranges them by the date when they produced their first official in the Song dynasty (qijia houxian 起家後先). ${ }^{34}$ The latter, by contrast, did not limit its coverage to the gentry clans or branches and celebrated the right of settlement, arranging different clans according to when they settled in the prefecture (ju suoqian Xin'an chaodai xianhou 據所遷新安朝代先後). ${ }^{35}$

\footnotetext{
${ }^{32}$ Peter Bol argues that examination participation—as opposed to examination success—was adequate in Song times for a man to claim himself as a shi versus merely one of the min 民, the commoners. Accordingly, the primary function of the examination system shifted "from the government's mechanism for recruiting shih [shi 士] for office to an institution maintained at government expense to acknowledge the elite status of shih families who could no longer secure official careers for all their male descendants." Peter K. Bol, "The Sung Examination System and the Shih," Asia Major 3.2 (1990), 155. It is important to note that the Song awarded degrees only to metropolitan examination graduates, so participation in the metropolitan examinations was equivalent, more or less, to receiving a juren degree in late imperial times. In this sense, the creation of lower-ranked degrees in the Ming, such as juren and shengyuan 生員, was tantamount to granting formal recognition of students and examination participants as members of the local gentry. Socializing with and being recognized by other shi was certainly crucial, but enrolling in local schools and participating in the examinations was probably also important for breaking into the circles of the shi and earning their recognition. As long as enrollment in local schools and examination participation were valued as an important form of certification of one's shi status, it would be difficult to argue that the $s h i$ was a self-ratifying elite whose status did not depend on state grant. Robert Hymes, "Sung Society and Social Change," in The Cambridge History of China, Volume 5, Part II, The Five Dynasties and Sung China, 960-1279 AD, edited by John W. Chaffee and Dennis Twitchett (Cambridge: Cambridge University Press, 2015), 621-22.

${ }^{33}$ Brian E. McKnight, Village and Bureaucracy in Southern Sung China (Chicago: University of Chicago Press, 1971), 106-7.

${ }^{34}$ Fei Zhu 費著, Chengdu shi zu pu 成都氏族譜 (Shanghai: Shanghai shu dian, 1994), 1a.

${ }^{35}$ Zhu Kaiyu 朱開宇, Keju shehui, diyu zhixu yu zongzu fazhan: Song Ming jian de Huizhou, 1100-1644 科 舉社會、地域秩序與宗族發展: 宋明間的徽州, 1100-1644 (Taibei: Guoli Taiwan daxue chuban zhongxin, 2004), 104-5; Harriet Zurndorfer, Change and Continuity in Chinese Local History: The Development of
} 


\section{Song Chen}

The rise of the gentry in local society, therefore, was a product of both institutional choices made by historical actors and long-term structural changes. The examination system was capitalizing on long-term structural changes, such as economic growth and the spread of printing technology. These changes, which made education more affordable and accessible outside the capital, had been underway for centuries and were beyond the control of political leaders. As an institutional channel for translating wealth into power, the examination system in the Song did not grant everyone from everywhere equal access to government service. Instead, it replicated-if not amplifiedregional disparities in economic development in the area of political participation. It ended the dominance of the capital in the examinations, but replaced it with the dominance of affluent, culturally ascendant regions, including the Zhejiang-Fujian coast and, to a lesser extent, the Chengdu basin of Sichuan. In the Song, it was these regions that benefited immensely from the new opportunities provided by the examination system. For this reason, Mingzhou was anything but typical. As a center of both domestic and overseas trade, Mingzhou was illustrative of the shift. It produced merely fifteen jinshi between 960 and 1040 but as many as 107 jinshi in the following eighty-seven years of the Northern Song. Its performance in the Southern Song was even more impressive. With a total of 747 local men receiving the jinshi degree between 1128 and 1279, it ranked third among all Southern Song prefectures. ${ }^{36}$ The experience in less advanced regions, one may imagine, would have been markedly different. Prefectures in North China, for example, with the exception of Kaifeng, produced only a tiny number of degree holders during the Northern Song. ${ }^{37}$ Northern Shanxi, liyama observes, was barely touched by the examination culture and the local literati population was negligible throughout the Northern Song (41).

The tension between upholding meritocratic principles and enlarging the scope of political participation fueled debate at the eleventh-century court. ${ }^{38}$ It was partially and temporarily resolved, ironically, by the Jurchen occupation of North China in 1127. A perfect complement to Lee's study on Mingzhou, Iiyama's book Kin Gen jidai no kahoku shakai to kakyo seido examines how local elite and local society evolved in vastly different historical contexts from the twelfth to the fourteenth century. He begins with the institutions of recruitment in the Jin and Yuan period, explores their social impacts in North China, and enriches his general discussion with a few case studies focused on Shanxi. One of Iiyama's most important contributions, I think, is to demonstrate how the Jurchen conquest changed the geography of examination success in the north and fostered the growth of a gentry class in northern society.

Despite Iiyama's emphasis on how differently literati were treated under the Jin and Southern Song, continuity between the Northern Song and Jin is also noteworthy. Although the Jurchens, especially the imperial Wanyan clan, nearly monopolized all high-ranking policy-making offices, it was the Chinese that satisfied the Jin's staffing needs at the lower levels of bureaucracy. From the very beginning, the Jin implemented a civil service examination system modeled on the Song and Liao practices. Over time, the Jin reformed it, expanded it, and relied on it as the primary

Hui-chou Prefecture 800 to 1800 (Leiden: Brill, 1989); Keith D. Hazelton, "Patrilines and the Development of Localized Lineages: The Wu of Hsiu-ning City, Hui-chou, to 1528," in Kinship Organization in Late Imperial China, 1000-1940, edited by Patricia Buckley Ebrey and James L. Watson (Berkeley: University of California Press, 1986), 137-69; Dai Tingming 戴廷明 and Cheng Shangkuan 程尚寬, Xin'an mingzu zhi 新安名族志 (Hefei: Huangshan shushe, 2004), 15.

${ }^{36}$ These numbers are based on my own counting of jinshi recipients listed in the 1320 edition of the prefectural gazetteer. Yanyou Siming zhi 延祐四明志 (1320 edition, reprinted in Song Yuan fangzhi congkan), 6.7b6.30a. John Chaffee reports 127 and 746 jinshi from Mingzhou in the Northern and Southern Song respectively. Chaffee, The Thorny Gates of Learning, 196.

${ }^{37}$ Ma Duanlin 馬端臨, Wenxian tongkao 文獻通考 (Taibei: Taiwan shangwu yinshuguan), 31.291.

${ }^{38}$ The most famous proponents on the two sides of this debate were Ouyang Xiu and Sima Guang. See Ma, Wenxian tongkao, 31.291-93. 
route for recruiting Chinese talent into the civil service. Furthermore, since well-established Kaifeng families had fled south and since the highly competitive southern literati were now living under a different regime, scholars in many areas of North China actually stood a greater chance of passing the examinations in Jin times. Thus, Iiyama argues, the scope of political participation expanded and classical education spread in North China in Jin times. This trend, similar to that in South China since the mid-eleventh century, is especially evident if we compare the first and second halves of the Jin dynasty.

In the first half of the Jin, Zhongdu circuit (now Beijing and its environs) was arguably the center of literati culture in North China. Until 1189 it seems to have consistently produced the largest number of graduates in the examinations. However, its success, unlike that of Kaifeng in the Northern Song, reflects its long-standing cultural legacies more than any advantage associated with its status as the capital of the Jin (Iiyama, 75). ${ }^{39}$ It was already the center of literati culture in Liao times. In the early years of the Jin, the dispersal of literati families in Kaifeng left no place in North China capable of challenging Zhongdu's cultural preeminence.

That said, Zhongdu circuit never dominated the examinations to the extent Kaifeng had in the Northern Song. Even in its heyday during the early Jin, it seems to have claimed no more than a third of the degree holders. ${ }^{40}$ Its dominance clearly tapered off by the late twelfth century. During the latter half of Shizong's reign (1161-89), the Jin implemented policies highly reminiscent of the Northern Song. The examination system expanded significantly, and the government expressed interest in reviving prefectural schools, though these schools restricted their enrollment to imperial clansmen, relatives of officials, and metropolitan examination candidates (Iiyama, 8586).$^{41}$ Estimates show that of the 10,000 or more degrees awarded in the entire duration of the Jin, the bulk were given in the latter half of the dynasty. ${ }^{42}$ It was scholars from outside Zhongdu circuit who seem to have benefited most from these expansions. According to the statistics provided by Iiyama, in the 1190s, for the first time in the Jin, Zhongdu circuit lost its position as the top producer of examination graduates. Between 1190 and 1200 more literati from Hedong South (now southern Shanxi) received the coveted degrees than those from Zhongdu circuit. In the meantime, the circuits of Hedong North, Hebei West, and Shandong West (roughly northern Shanxi, western Hebei, and western Shandong today) all closed their gap with Zhongdu dramatically. The percentage of degree holders from Zhongdu circuit dropped to $15 \%$, and it remained at that level until the end of the dynasty (Iiyama, 74-77).

The result was the appearance of a gentry class across North China in the Jin. As Iiyama demonstrates, the size of this gentry population, though only one-tenth of that in the Southern Song, was at least twice — and possibly three or four times - that in the late Northern Song (156-64). Northern Shanxi was a case in point. Situated on the borders between the Chinese, Khitans, and Tanguts, it was best known for its professional military families (jiangjia 將家) since the fall of the Tang and was barely touched by the examination culture of the Northern Song (114-18). Shanxi produced a

\footnotetext{
${ }^{39}$ Zhongdu did not become the capital of the Jin until 1153, but its elevation did not seem to give its scholars any competitive edge in the examinations. If anything, the percentage of examination graduates from the Zhongdu circuit declined slightly from $33 \%$ between 1115 and 1149 to $27 \%$ between 1150 and 1189. Its dominance in the examinations does not seem to have been affected by the Jin decision in 1040 to implement a uniform examination on former Song and Liao literati, either.

${ }^{40}$ By comparison, Kaifeng and the Directorate of Education continued to produce one-third to half of the jinshi in each examination cycle between 1059 and 1063. Ma, Wenxian tongkao, 31.291.

${ }^{41}$ Tuotuo 脫脫, Jinshi 金史 (Beijing: Zhonghua shuju, 1975), 51.1131-40; Peter K. Bol, “Seeking Common Ground: Han Literati under Jurchen Rule," Harvard Journal of Asiatic Studies 47.2 (1987), 473-76.

${ }^{42}$ Jing-shen Tao, "Political Recruitment in the Chin Dynasty," Journal of the American Oriental Society 94.1 (1974), 24-34; Jing-shen Tao, The Jurchen in Twelfth-Century China: A Study of Sinicization (Seattle: University of Washington Press, 1977), 52-67; Bol, "Seeking Common Ground," 478-79, 479n48.
} 


\section{Song Chen}

very small number of degree holders under the Northern Song and Liao, and they came almost exclusively from Taiyuan and places to its south. It was only in the Jin, Iiyama shows, that classical culture spread to northern Shanxi and literati population there expanded dramatically (111-16). ${ }^{43}$ Several literati families emerged during the Jin, including the Lius 劉 of Hunyuan 渾源 and the Yuans 元 of Xiurong 秀容, both of which boasted a tradition in belles-lettres. The Yuans, for example, began as a military family in the Northern Song and produced their first degree holder in 1157 under the Jin. Thereafter, they continued to take the examinations and hold civil offices using facilitated degrees or the yin privilege, even though they did not produce another metropolitan examination graduate until 1221 (110). The Lius were even more successful, having at least two metropolitan degree holders in each generation from their initial success in 1124 until the fall of the Jin (118-19).

In both the Song and Jin, it was clearly the examination system that provided the institutional underpinning for the rise of the gentry in local society. It offered incentives for local elite families to participate in a national culture, opportunities for them to enter government service, and state certifications for claiming themselves as a prestigious stratum in local society. The breakdown of the examination system in the Yuan dynasty, therefore, presented a serious challenge for the local gentry in both North and South China.

Lee and Iiyama both emphasize notable discontinuity brought on by the Mongol conquest and closely associated with institutional changes in the Yuan. They show that scholars in the Yuan period faced an array of obstacles to gaining official rank and maintaining their local status. Although the Yuan state continued to provide ways for local literati to define themselves as a social stratum different from the commoners, such as registering themselves as "Confucian households" ( $r u h u$ 儒戶) and enrolling in local government schools, these opportunities were few and the fiscal and legal privileges associated with such status, if any at all, were very limited and insecure and often subject to the whims of local officials (Lee, 216; Iiyama, 335). Moreover, their access to political power also became more restricted than ever before. With classical education no longer a prerequisite for entering government service in Yuan times, scholars now had to compete with military talents, financial experts, and men with other types of specialized expertise, to whom the gate to power had opened wide in the Yuan period. The situation was exacerbated by the breakdown of the examination system. Though a shortcut to high office later in the dynasty, the examinations were not revived until 1314 and graduated only a negligible number of candidates for the rest of the dynasty. ${ }^{44}$ What added to the difficulty of translating cultural attainments into political and social status was a new definition of what counted as cultural attainments. When the examinations were resumed, they tested Neo-Confucian moral philosophy rather than belles-lettres, the favorite subject for candidates during the Jin and much of the Southern Song. As the importance of the examinations declined, many scholars began to take up teaching jobs in local academies, clerical posts in local administrations, and managerial assignments under the Mongol nobility who had fiefs (ayimaqs) nearby. Promotion to a higher rank, though possible, was competitive and uncertain, relying heavily on one's ability to secure recommendations from high-ranking officials or Mongol noblemen either at court or in the provinces (Iiyama, 216-89). ${ }^{45}$

Very few literati families adapted themselves successfully to these changes. The Duans 段 of Jishan 稷山 in southern Shanxi, discussed at length by Iiyama, was one of the exceptions. Having produced one degree holder in the late Northern Song and three others in the Jin, the

\footnotetext{
${ }^{43}$ Chaffee, The Thorny Gates of Learning, 202.

${ }^{44}$ In the entire Yuan period, only four men from Mingzhou and seven from the Fen river valley of southern Shanxi passed the examinations. Iiyama, Kin Gen jidai no kahoku shakai to kakyo seido, 304, 309n14, 363. Lee, Negotiated Power, 217.

${ }^{45}$ See also Iiyama's article in this issue.
} 
Duans continued to attain official rank until the early fourteenth century. Their success owed mainly to two of their strategic moves. On the one hand, they advisedly shifted their focus of learning from literary composition to moral philosophy, and on the other hand, by having family members serve in clerical offices at court, they built up connections in the capital with court officials like Yan Fu 閻復 (1236-1312), through whose recommendations more family members enrolled in the Directorate of Education and received bureaucratic appointments (Iiyama, 359-64).

Most literati families, however, were not so lucky. In Shanxi, liyama shows, literati families that produced degree holders in the Jin almost all disappeared from historical records in the Yuan times (Iiyama, 351). In Mingzhou, Lee contends, even prominent Southern Song families, like the Shis and Lous, could not avoid gradual decline, and many struggled to preserve their elite status by embarking on a wide range of career paths, such as clerks, teachers, and sea transport managers (Lee, 216-17). The result was a noticeable change in both the makeup and social character of the officeholding local elite. It was no longer constituted solely by men with a classical education. Instead, they were joined by those who proved their worth in more practical fields of activity, such as military service and maritime transport. Among these men with practical skills, some were born to former literati families, and others, like the Nis 倪 of Mingzhou, came from more modest backgrounds (Lee, 223-24).

The breakdown of the examination system, as Lee and liyama both rightly point out, put literati and other aspirant local families in a weak position vis-à-vis the government. It deprived local literati not only of a reliable means of achieving high rank but also of an officially recognized mechanism of defining their group identity and social status (Lee, 207-8). Since fiscal and legal privileges were often granted at the discretion of local officials and gaining political success was ever more dependent on social connections, maintaining an amicable relationship with local and court officials became all the more important. Thus, ironically, as Lee points out, the breakdown of the examination system decreased only the supply of, not the demand for, connections to the state in Yuan times. It turned these connections into "a rare commodity" for the local elite and intensified their need to reach out actively to local officials, which is evident in the lavish praise they heaped on the Yuan state and its local agents in a variety of panegyrics, such as "parting prefaces" (songxing $x u$ 送行序) and “stele in appreciation for departing officials" (qusi bei 去思碑) (Lee, 258-59, 263). ${ }^{46}$ They took pride in their connections with Yuan officials by circulating these panegyrics in their literary collections. In the way that Iiyama puts it, whatever privileges the Yuan local elite enjoyed were no longer guaranteed by established institutions and time-honored consensus (kanshüteki 慣習的). For that reason, the process by which the Yuan local elite gained privileges and established itself as local leaders was, at the same time, also a process that empowered the Yuan state (Iiyama, 206).

As notable as they were, these changes should not cloud our vision of the continuity between the Yuan and earlier times. Despite heavy reliance on personal connections, the "diversification of paths to government service” (shusshi keiro no takika 出仕経路の多岐化), to use Iiyama's phrase, recognized the value of distinctive local traditions which nurtured talents in, for example, military service (e.g., in Dingxiang 定襄 county of northern Shanxi; Iiyama, 185-91, 205) and maritime transport (e.g., in Mingzhou; Lee, 222-25). As a result, it offered opportunities for political participation across the empire without privileging a few affluent and culturally ascendant regions, an issue which had constantly plagued the Song and was only partially resolved by political disunity in the twelfth and thirteenth centuries. The long-term trend of expanding political opportunities outside capital circles, therefore, continued in Yuan times and benefited especially those regions which had lacked a strong tradition of classical education (Iiyama, 198, 205).

\footnotetext{
${ }^{46}$ See also Chen Wenyi 陳雯怡, "Networks, Communities, and Identities: On the Discursive Practices of Yuan Literati” (PhD diss., Harvard University, 2007), 396-97.
} 


\section{Song Chen}

Secondly, as in the Song and Jin, the expansion of political opportunities in the Yuan created a locally embedded, office-holding elite in the provinces, although not all members of this elite were literati. In fact, government service and local dominance became ever more entangled in the Yuan period. In Dingxiang, for example, at the beginning of the Mongol conquest, the appointment of local men to county and prefectural offices meant little more than an official recognition of whatever dominance these strongmen had already achieved in their home locales in exchange for their willingness to cooperate with the conquerors (Iiyama, 190-93). Even after Mongol rule took hold, as time progressed many of those who pursued a career in the new government continued to be employed near their hometowns as teachers, clerks, officers, tax collectors, and sea transport supervisors. Even for those who set their eyes on national prominence, a solid local base was critical. Many started out on their careers locally and first proved their worthiness to local officials or to Mongol noblemen enfeoffed nearby. Clerical service in the central government and networking in the capital were extremely valuable, but these opportunities were few and highly unpredictable. Even the Duans, Iiyama shows, saw their carefully constructed capital networks collapse following the death of Yan Fu in 1312. Thereafter, the Duans failed to produce a single officeholder during the Yuan. Many of those who did try their luck at the capital often made the trip only after they had gained administrative experience and built up connections near their homes (Iiyama, 233-34).

With careers in government so unpredictable and so tightly bound to a family's social station at home, it is not difficult to understand why many office-holding families in the Yuan, whether from Shanxi or Mingzhou, seem to have continued to live in their native places instead of relocating to the capital. Their marriage networks, too, were reminiscent of the Song political elite after the mideleventh century, centered on their hometowns but extending frequently to nearby counties and prefectures (Iiyama, 192-94; Lee 226-32). The Yuan political practice, in other words, seems to have carried on the long-term trend that began in the Song period: the expansion of political opportunities outside the capital and the attendant rise of a local elite that claimed an exalted social standing on the basis of its connections to the state. The diversification of paths to office in the Yuan times, in fact, gave this elite a more widespread presence across the empire rather than limiting it to only a few culturally ascendant areas like Song dynasty Mingzhou.

This was evidently a major reason that deterred the first few Ming emperors from fully reviving the examination system. Reintroducing southern scholars into the civil service examinations under a unified empire would almost certainly force northern literati out of the jinshi ranks and consequently narrow the scope of political participation to an extent unseen in two hundred years. The metropolitan examination of 1397 attests to this. Initially, all fifty-one graduates for that year were southern literati. The emperor was outraged, and his desire to ensure a balanced representation of different regions in his government was evident in his decision to reissue the roll of jinshi degree holders with sixty-one new graduates, all northerners. Only after 1450, when an acceptable regional quota system had been put into place, did civil service examinations become the chief route to office. ${ }^{47} \mathrm{~A}$ wider geographical scope of political participation was also realized, to a limited degree, by allowing provincial examination graduates (juren 舉人) to hold office. Thus, although the rise of the gentry-locally rooted literati families who had official titles, examination degrees, or student status in local government schools-began in Song times, it was not until the mid-fifteenth century that it extended beyond a few culturally ascendant prefectures. The dramatic increase of metropolitan and provincial degree holders after 1440 that McDermott documents, both in the Shanhe Chengs' descent group and in Huizhou at large, is also evidence of this change (McDermott, 260-61). ${ }^{48}$

\footnotetext{
${ }^{47}$ Benjamin A. Elman, A Cultural History of Civil Examinations in Late Imperial China (Berkeley: University of California Press, 2000), 94-97.

${ }^{48} \mathrm{Du}$ notes that jinshi degree holders from Zezhou reached a historical peak between the late sixteenth and early eighteenth centuries (Du, 94). Evidence suggests, however, that examination success in Zezhou and
} 


\section{GOVERNMENT AND LOCAL ELITE ACTIVISM IN THE SONG AND YUAN}

The "localist turn" in the Song period marked the onset of the secular rise of a gentry class in local society. Already in the Song, this was accompanied by the gentry's aggressive moves to affirm a collective identity and expand their role in local governance. They did so by promoting new institutions and practices and repurposing existing ones. In Southern Song Mingzhou, for example, the gentry revived and actively promoted the community drinking ceremony (xiang yinjiu li 鄉飲酒禮) and, by limiting its attendees to "local officeholders and literati" (xiang dafu shi 鄉大夫士), made it a collective ritual exclusively for the local gentry and a public demonstration of their social distinctiveness (Lee, 171). The gentry also claimed for themselves the role of mediators between local society and government, presenting themselves as spokesmen for local interests and advisers on local policies. Government schools, which earlier reformers like Wang Anshi 王安石 (1021-86) had promoted as an instrument of imposing ideological uniformity and as a training ground for capable officials, were touted in many Southern Song writings as a venue for local literati to "deliberate on governing" (yizheng 議政) and offer counsel to local officials (Lee, 163-66). In the Yuan, local literati continued to present themselves as "representative voices of local society." In the panegyrics they composed, Lee argues, they included subtle exhortations to local officials, "informing them of priorities in local governance" (Lee, 254). Therefore, as Lee underscores, the literati's growing attachment to their native places by no means implies their separation from the state. Rather, the localization of the national political elite was, when viewed from the local perspective, also the politicization and nationalization of the local elite. As new state-certified status markers were introduced into the local scene, complicating the definition of social positions, gentry families asserted their distinctiveness and prestige against other members of the local elite precisely in terms of their connections to the state and their ability to negotiate with it.

The close relationship between the state and the gentry also stands out in Lee's discussion of local activism in Southern Song Mingzhou. He argues that although the Southern Song witnessed an upsurge of communal efforts spearheaded by the local elite, this does not imply a retreat of the state from local society. Rather, the success of these efforts depended heavily on the local elite's cooperation with local government. Not only did the local government, in general, make a greater contribution than local elites in the development of Mingzhou, but the financial and administrative support it provided were also indispensable to many local projects initiated and advocated by local elites. Very few undertakings-including institutions and practices of central importance to the gentry, such as the renovation of schools and the performance of the community drinking ceremony-were accomplished without government support. As Lee aptly puts it, "the rise and spread of local [elite] activism during the Southern Song period... was undergirded by the activism of local government" (198). Both Lee and McDermott show that even landed trusts of kinship groups, including the famous one started by Fan Zhongyan and the charitable estate of the Lous

\footnotetext{
Shanxi province in general had been in an upward trend since the mid-fifteenth century. The total of metropolitan and provincial degree holders from Zezhou increased significantly after the mid-fifteenth century. See Yongzheng Zezhou fuzhi 雍正澤州府志 (Zhongguo difangzhi jicheng 中國地方志集成 edition), 29.1a-29a. While the whole Shanxi province produced only 129 jinshi between 1368 and 1450, it produced 436 between 1451 and 1550 and 531 between 1550 and 1644. Its three southeastern prefectures-including Zezhou, Lu'an 潞安, and Qinzhou 沈州—also saw a turning point in their examination success in the midfifteenth century. While these prefectures produced only 27 jinshi between 1368 and 1450, they produced 89 and 102 jinshi in the second and last centuries of the Ming respectively. Chen Haodong 陳浩東, “Mingdai Shanxi jinshi jiguan shikong fenbu yanbian chutan” 明代山西進士籍貫時空分佈演變初探, Shanxi shida xuebao (shehui kexue ban) 山西師大學報(社會科學版) 39.3 (2012), 104-5. Chen's data are collected from Zhu Baojiong 朱保昫 and Xie Peilin 謝沛霖, Ming Qing jinshi timing beilu suoyin 明清進士題名 碑錄索引 (Shanghai: Shanghai guji chubanshe, 1979).
} 
in Mingzhou, had difficulty lasting beyond a few generations without timely intervention of local government in the Song and Yuan times (McDermott, 133-39; Lee, 234).

Why so? The answer, I think, has to do with both opportunity and capability. If it was at all possible to use government funds or someone else's money to advance one's own goals, then why not? The substantial investment that the Mingzhou government made in local projects during the Southern Song certainly demonstrates the state's resourcefulness and interest in sustaining local economic and cultural development, but, from another perspective, it can also be seen as evidence of the Mingzhou elite's exceptional ability in swaying government decisions and channeling government revenues to serve the elite's agendas. Having office-holding native sons, as was increasingly the trend after the mid-eleventh century, certainly helped. This is particularly evident in the construction of the Wujin dike (Wujin qi 烏金碶) that Lee discusses in great detail. In this case, the local elite of Mingzhou first petitioned Shi Miyuan 史彌遠 (1164-1233), a native son and then grand councilor, and Shi, in turn, did his job of urging the prefectural government to take action and cover the bulk of the expenses (Lee, 114-16). With all these opportunities of using government funds for local purposes, private investment was not necessary. It became necessary only when the state was unable to bear the full costs or when the local elite lost its influence over local officials. Thus, it is not difficult to understand why, given the tighter budgets of county administrations and the dynastic crisis, local elite contributions were more conspicuous at county levels and especially in the early years of the Southern Song (Lee, 97, 156). Nor is it difficult to understand why, given the literati's modest political success, insecure social station, and greater cultural distance from local administrators, local projects in Yuan-dynasty Mingzhou received far less financial support from the local government (Lee, 207, 232-44).

The prominent role of Mingzhou government in supporting local development was evidently also a result of the local elite's inability to mobilize funds and manpower by itself. Probably large-scale projects at all times had to depend heavily, even though not exclusively, on government support. As Wei Xian 魏峴, a retired official and sojourner of Mingzhou who took an unusual interest in water management, learned from his own experience, "I often contributed my own money to hire people and dredge the streams, but the resources of private households can never match those of the government" (Lee, 121 [translation modified]). That said, Lee's account of Southern Song Mingzhou portrays a local elite whose heavy reliance on the formal bureaucratic apparatus in carrying out local projects contrasts markedly with what historians have long observed in the MingQing period. The reason, I think, has to do with the absence of social institutions in Song times that the local elite could rely on to mobilize resources in the community without resorting to the state apparatus.

In the Song, the most resource-rich institutions outside the state seem to have been Buddhist establishments, which had owned land and forests and engaged in a wide variety of profitmaking activities for centuries. In the early thirteenth century, Mingzhou had a total of 305 Buddhist temples, each owning on average $229 \mathrm{mu}$ of farming land and 293,723 $\mathrm{mu}$ of forests. ${ }^{49}$ Their relationship with the government and the local elite was complicated. Officials and wealthy local families were sometimes patrons, sometimes predators, and at other times collaborators. Many local families set up merit cloisters or private chapels funded with land or just rents to look after their ancestral graves and provide seasonal offerings; others registered their land under the nominal ownership of monasteries to evade taxes and labor service charges. It was not uncommon, however, for the very powerful to simply seize a temple and its property by force and then have it designated as their grave temple. Many literati associated with monks and studied at monasteries, and the Song government typically used temple grounds to host civil service examinations. These

\footnotetext{
${ }^{49}$ Huang Minzhi 黃敏枝, “Songdai Liangzhe lu de siyuan yu shehui” 宋代兩浙路的寺院與社會, Chengda lishi xuebao 成大歷史學報 5 (1978), 330-36.
} 
temples played an active role in local development throughout the Song, building and maintaining bridges, roads, dikes, and floodgates, sometimes all on their own, while at other times in collaboration with the local government and the local elite. ${ }^{50}$ At the very least, Buddhist establishments were clearly the only corporate entities that had their own fiscal autonomy and acted independently in the local community. Their resources - even lands donated to private chapels-were, at least on paper, beyond the reach of the local elite. After all, the purpose of setting up these grave chapels was precisely to set aside a portion of the family fortune for the long-term upkeep of ancestral graves and sacrifices, entrusting its management to the monks, and thus protecting it from unworthy descendants.

In the absence of effective means for pooling resources and coordinating action, it is not surprising that the local elite in Southern Song Mingzhou would rely heavily on the organizational capacity provided by local government, especially in projects that required routine maintenance. To ensure regular dredging of Dongqian Lake (Dongqian $h u$ 東錢湖) and the Tuoshan Dam (Tuoshan yan 它山堰), for example, the government of Mingzhou not only established landed estates with prefectural funds to cover the expenses but also arranged for the management of these estates. In the Song, the government typically assigned each rural household into one of five grades based on its assets and made each household take turns to fulfill certain labor service obligations appropriate to its grade, such as tax collection and local policing. In the above cases, evidence shows that the same mechanism was employed in assigning managerial duties over the endowed fields. These duties were either entrusted to village servicemen, such as the canton leader (xiangzhang 鄉長), or rotated among households in the top grades ("graded households in nearby cantons with the greatest material resources" [近鄉等戶物力最高者]; “upper households in the canton” [鄉之上戶]). The only non-governmental institutions involved in these projects were “nearby Buddhist monasteries" (jinhu siyuan 近湖寺院), where harvested grain from the endowed fields was stored. ${ }^{51}$

By comparison, kinship institutions were remarkably weak in the Song and Yuan. As will be discussed later, collective ancestral rites were practiced by small kinship groups by the gravesite and lineage halls did not exist. Although references to less institutionalized charitable action towards kinsmen were abundant, kinship-based charitable estates were few in Song and Yuan times. Where corporate estates of descent groups existed, they were usually very small in size, intended mainly to pay for sacrificial expenses, and under the constant danger of being divided up. ${ }^{52}$ Even prominent families, like the Shis of Mingzhou, had neither charitable estates nor corporate sacrificial lands. ${ }^{53}$ The principal form of rural organization was the village worship association. Although it gradually took on some nonreligious tasks after the early thirteenth century, if not earlier, the village worship association remained primarily a ritual organization until at least the mid-Ming and owned minimal property. ${ }^{54}$ It is the long-term evolution of these local institutions,

\footnotetext{
${ }^{50}$ Huang Minzhi 黃敏枝, “Songdai Liangzhe lu de siyuan yu shehui," 341-45; Huang Minzhi 黄敏枝, Songdai fojiao shehui jingji shi lunji 宋代佛教社會經濟史論集 (Taibei: Taiwan xuesheng, 1989), 413-42.

${ }^{51}$ Lee, Negotiated Power, 110, 120; Baoqing Siming zhi, 12.22b, 12.25b.

${ }^{52}$ Patricia Buckley Ebrey, "The Early Stages in the Development of Descent Group Organization," in Kinship Organization in Late Imperial China, 1000-1940, edited by Patricia Buckley Ebrey and James L. Watson (Berkeley: University of California Press, 1986), 40-44.

${ }^{53}$ Richard L. Davis, "Political Success and the Growth of Descent Groups: The Shih of Ming-chou during the Sung," in Kinship Organization in Late Imperial China, 1000-1940, edited by Patricia Buckley Ebrey and James L. Watson (Berkeley: University of California Press, 1986), 85.

${ }^{54}$ This is apparently the reason why, as McDermott observes, in the first half of the Ming when Huizhou's lineages began to expand their power at the expense of their institutional rivals in the countryside, their struggle with village worship associations was "primarily political" and their conflict with Buddhist establishments "by contrast, was primarily over economic and ritual matters" (169).
} 
from the Song to the Ming-Qing, that McDermott and Du have focused on in their studies. It is to the history of these institutions we will turn now.

\section{VILLAGE WORSHIP ASSOCIATIONS}

McDermott and Du have both demonstrated that, in Huizhou and Zezhou alike, villages became more organized on their own terms in Song times. But they were organized not on the basis of common descent, but on the basis of common residence and joint participation in the worship of local gods. $\mathrm{Du}$, in particular, provides a compelling account of the appearance of village worship associations as a form of communal organization in Northern Song Zezhou and the expansion of their power in the following centuries. Placing their works within the broader scholarship on religious and social history suggests several related areas of change. First, social and religious life in the village acquired an institutional form unknown before Song times. Collective worship of earth spirits (she 社) had a history going back to antiquity. In the Han dynasty, the government mandated seasonal sacrifices, also called she, to earth spirits at all levels of administration, from commanderies and districts down to administrative villages ( $l i$ 里). These sacrifices were organized by officials and village officers. As early as the Han, rural residents also started organizing mutualaid societies (dan 僤) and Buddhist worship associations (yiyi 邑義 or fayi 法義), which had compacts and managers and recruited members on a voluntary basis. ${ }^{55}$ These organizations, especially the Buddhist worship societies, flourished after the fall of the Han and many, by the Tang period, also called themselves she 社 and had become formally organized. ${ }^{56}$ In the Song, if not in late Tang, these two aspects of she - as communal sacrifices to earth spirits and as a form of voluntary organization for mutual aid or collective worship — began to conflate, leading to the rise of an "inclusive territorial institution" in the countryside based on ascriptive membership and centered on collective worship which, again called she, were often - though not always - coextensive with a hamlet or natural village (Du, 8-10, 254-57; McDermott, 53-58). ${ }^{57}$ As a widespread form of village selforganization, these she also provided the building blocks for multi-village worship communities, which began to emerge in the Northern Song.

The formation of these multi-village worship communities resulted from momentous changes in local religious life in Song times. Increasingly each god or spirit was given a distinct identity with close local ties and thereby transformed into a local tutelary deity. Recent scholarship has shown that since the late Tang, and especially during the Song, previously nameless earth spirits which were believed to literally inhabit the soil were now identified as historical or legendary figures in local history. They "shed the violent, morally ambivalent character and grotesque forms" of their older selves and became guardians of local welfare. They were worshipped not because

\footnotetext{
${ }^{55}$ Yang Hua 楊華, “Zhanguo Qin Han shiqi de lishe yu sishe” 戰國秦漢時期的里社與私社, Tianjin shifan daxue xuebao (shehui kexue ban) 天津師範大學學報(社會科學版) 184.1 (2006), 21-28; Ning Ke 寧可, “Han dai de she” 漢代的社, Wenshi 文史 1980.9, 7-14; Ma Xin 馬新, “Lun Liang Han xiangcun shehui zhong de lishe" 論兩漢鄉村社會中的里社, Wen shi zhe 文史哲 1998.5, 90-94.

${ }^{56}$ Hao Chunwen 郝春文, “Dong Jin Nanbeichao foshe shouling kaolue” 東晉南北朝佛社首領考略, Beijing shifan xиeyuan xиebao (shehui kexue ban) 北京師範學院學报(社會科學版) 1991.3, 49-58; “Dong Jin Nanbeichao shiqi de fojiao jieshe” 東晉南北朝時期的佛教結社, Lishi yanjiu歷史研究 1992.1, 90-105; Fu Xiaojing 傅曉靜, “Tang dai minjian sishe de zuzhi xingshi yu huodong fangshi” 唐代民間私社的組織 形式與活動方式, Lilun xuekan 理論學刊 116.4 (2003), 142-43; “Lun Tang dai xiangcun shehui zhong de she” 論唐代鄉村社會中的社, Qingdao daxue shifan xueyuan xuebao 青島大學師範學院學報 17.1 (2000), 21-25.

${ }^{57}$ For late Tang examples of the she as a rural organization for collective worship of the earth god, see Fu Xiaojing 傅曉靜, “Tang dai minjian sishe de jiben gongneng” 唐代民間私社的基本功能, Qi Lu xuekan 齊魯 學刊 176.5 (2003), 41.
} 
their angry spirits needed to be appeased, but more because they responded promptly to a wide range of local needs and demonstrated their efficacy in protecting the local community. ${ }^{58}$ In Huizhou during the Song and Yuan, McDermott shows, earth spirits were increasingly anthropomorphized into historical celebrities with a local connection一-such as Cheng Lingxi 程靈洗 and Wang Hua 汪華—who usually came from a military background, founded the village, or at some time protected the village or its general area (56-61). Rain gods in southern Shanxi, argues $\mathrm{Du}$, underwent a similar transformation. Before the Song, local people made prayers for rain to nameless dragons near local rivers and lakes, where they supposedly dwelled (24-25). Come the Song, rain gods were given an identity with local ties, real or fictitious. In some areas, local people worshiped a historical figure like Cheng Tang 成湯, the first king of Shang, as a rain god and claimed that it was near a local river where the king had successfully prayed for rain in history (28-36). Where such local connections were not found, local ties were invented on the basis of efficacy. The cult of dragons continued, but it was now believed that the White Dragon on Mt. Yan (Yanshan bailong 崦山白龍) was particularly efficacious (36-43). In the high tide of imperial promotion of Daoism, the Jade Emperor was also appropriated as a rain god in Shanxi, but again prayers to him in a particular village was believed to be more effective than elsewhere (51-52). These deities were increasingly adopted by local people as their tutelary gods from the Song onward. These changes, I think, paved the way for wide-ranging religious networks to emerge between villages. The greater emphasis on the gods' role as a guardian of-rather than an threat to-local welfare and the process of "branding," which differentiated otherwise nameless gods from each other, created a market for different gods, each with his or her distinct identity and associated with a different locale, to compete for patronage with his or her ability to address local needs. Some deities became superstars and attracted a large following in a wide area. These deities did not displace the tutelary god of each individual village (Du, 59-61). But they and the places they were associated with evolved into, to use the words of Richard von Glahn, "focal points for communal identity and welfare" in a wider geographic area and thereby gave rise to multi-village worship communities. The village worship association also acquired a new significance: it became the principal form in which each constituent village participated in the collective activities of these multi-village communities. ${ }^{59}$

A related change in the Song religious practices was the growing tendency to shelter these tutelary gods in a small shrine rather than making offerings to them under a tree, near a lake or river, or at an open-air altar (Du, 53) ${ }^{60}$ The building of these shrines seems to have flourished after the eleventh century, probably reflecting both local economic growth and a more tolerant religious policy by the Song government. ${ }^{61}$ Such an activity frequently required cooperation among several natural villages. In Shanxi, for example, the 1076 construction of a shrine dedicated to the Jade Emperor in Fucheng 府城 village was sponsored by fifteen village worship associations within a radius of five

\footnotetext{
${ }^{58}$ Richard von Glahn, The Sinister Way: The Divine and the Demonic in Chinese Religious Culture (Berkeley: University of California Press, 2004), 164-65, 296-97n96. Von Glahn's discussion draws mostly from Japanese scholarship. For a review of Japanese scholarship on earth spirits and she in the Song dynasty, see Matsumoto Kōichi 松本浩一, “Sōdai no sha to shibyō" 宋代の社と祠廟, Shikyō 史境, 38-39 (1999), 115. See also Sue Takashi 須江隆, “Tō Sō jidai no shibyōsei no kenkyū”唐宋時代の祠廟制の研究 $(\mathrm{PhD}$ diss. Tohoku University, 1999), 19-124.

${ }^{59}$ Von Glahn, The Sinister Way, 165.

${ }^{60}$ For a similar development in Fujian and its relationship with the she, see Yao Zhengzhi 姚政志, "Nan Song Fuzhou minjian xinyang de fazhan” 南宋福州民間信仰的發展 (Master's Thesis, National Chengchi University, 2010), 48-78.

${ }^{61}$ Mizukoshi Tomo 水越知, “Sōdai shakai to shibyō shinkō no tenkai: Chiiki kaku to shite no shibyō no shutsugen 宋代社会と祠廟信仰の展開: 地域核としての祠廟の出現, "Tōyōshi kenkȳu 東洋史研究 60.4 (2002), 1-38.
} 
kilometers of Fucheng, each headed by a deacon, elder, registrar, or the like-titles borrowed from Buddhist and government institutions. Once constructed, the shrine became the corporate property of those villages participating in its construction, which, in turn, strengthened both the multi-village alliance and its basic organizational units (i.e., its constituent village worship associations). In many cases, it created a multi-village alliance centered on the shrine that basically survived into the eighteenth century ( $\mathrm{Du}, 56-59)$. Likewise, the construction of the White Dragon Shrine on Mt. Yan also involved several villages. After a Yuan-dynasty renovation, it became the corporate property of four participating village worship associations, forming an alliance that also lasted even until today (Du, 40-42). ${ }^{62}$

These developments did not take place in the absence of imperial authority. On the one hand, the Song court served as a powerful source of legitimacy that loomed large in the entire process. Cheng Tang was a sage-king in the Confucian tradition. The Jade Emperor was a Daoist deity who received generous patronage from the court (Du, 25-26). Cheng Lingxi and Wang Hua, while protecting the local community from the rebels, also demonstrated their loyalty to the dynasty (McDermott, 57-60). The adoption and appropriation of these religious symbols for local purposes, therefore, also reaffirmed the authority of the state in the cultural and religious realms. The court's bestowal of noble titles was also valued as an explicit form of legitimation, especially for those deities who lacked historical ties to the dynasty and its cultural traditions. The strenuous effort of local people to prove that the White Dragon on Mt. Yan had actually received enfeoffment from the Tang and Song court underscores the importance of state recognition ( $\mathrm{Du}, 38-39)$.

On the other hand, the village worship organization's organizational capacity for mobilizing local resources and coordinating communal activities made it the government's chief target for cooptation after the thirteenth century. In 1206, the Jin made the village worship association the basic unit of its rural administration, requiring its head to assist the village head in registering the local population, collecting taxes, maintaining order, and promoting agriculture. In the Yuan, its duties were further extended to the running of a village school and its shrine received generous patronage from local officials (McDermott, 64; Du, 70-71). The early Ming government continued to have the village worship association function as the basic unit of its rural administrative structure, but it also made more aggressive moves to bring its ritual practices into line with canonical requirements. Then in the early sixteenth century it further attempted to have some Huizhou village worship associations take on new tasks of rural governance, such as running village granaries and providing moral-instruction lectures (McDermott, 180-81; Du, 200-216, 257). Although these early and mid-Ming government efforts had limited success, these policies attest to the village worship association's ubiquitous presence in the countryside and the state's growing interest in coopting this rural institution and prescribing and regulating its functions.

In sum, the Song witnessed the beginning of rural residents organizing themselves based on common residence and shared religious symbols. Village worship associations (she) began to develop when collective worship or mutual aid societies (she), previously based on voluntary subscriptions, acquired an ascriptive and territorial dimension and came to define the community of a village or hamlet which participated in seasonal sacrifices (the she sacrifices) to the same local deity. These village-wide associations seems to have developed greater organizational capacity from the eleventh century onward, because the rise of supra-village tutelary gods and the growing trend of worshipping them in shrines, rather than in the open air, required the participating villages to marshal local resources for the construction of shrines and to coordinate their religious activities. The tutelary god and the supra-village shrine where he or she was sheltered, then, also served as a binding force, both spiritual and economic, for an enduring alliance among the

\footnotetext{
${ }^{62} \mathrm{Du}$ also notices a similar phenomenon in a branch shrine dedicated to Cheng Tang. Du, Cunshe chuantong yu Ming Qing shishen, 37.
} 
component village worship associations. As such, these village worship associations and multivillage alliances that were built on top of them, as an organizational framework for local life in Song times, evolved primarily as a result of local, rather than imperial, forces. They also enjoyed remarkable independence from the gentry, who, after all, had not yet become a recognizable social stratum in Shanxi and many other areas at the time. This arguably made their heads and managers another type of local elite-as opposed to the gentry-whose power was rooted in local institutions rather than in official titles or degrees conferred by the state.

But the Song was only the beginning. From the Song to the first half of the Ming, the village worship associations seem to have controlled little, if any, corporate property besides their communal shrines, which, in turn, seems to have limited their sphere of activity largely to local religious affairs, despite the government's repeated attempts to have them perform some duties of rural governance. It was only after the mid-sixteenth century that the village worship association embarked on a sustained expansion in its resources, responsibilities, and coercive power and gradually evolved into a property-holding, self-governing body in the countryside.

In Zezhou, Du contends, some associations began to own corporate property and engage in moneylending by the mid-sixteenth century (226). No later than the late Ming, the village worship association began to expand its sphere of activity beyond religious affairs and claimed the power to police its members. In 1651, after a large-scale renovation of its local shrine dedicated to Cheng Tang, the worship association of Guoyu 郭峪 market town in Zezhou set up two landed estates, tightened regulations on the use of its collective property, and threatened to enforce them with regular policing. Three years later, it assumed responsibility for the upkeep of the town's defensive wall and its attached living spaces. Through "public discussion of the entire association" (heshe gongyi 闔社公議), it publicized a set of rules regulating the use and management of these structures, asserted its power to collect rents and impose fines, and declared these revenues its corporate property. This provided a stable source of income to cover the association's routine operating expenses (137-40). The authority of village worship associations underwent an even more dramatic expansion in the mid-Qing. In the mid-eighteenth century, many village worship associations no longer relied merely on voluntary donations to finance public projects but instead imposed levies directly on their members based on the acreage of their landholdings. Thenceforth, "shares in the association" (shefen 社分) came to denote a bundle of rights and obligations associated with landownership and was transferred during land transactions. After the mid-Qing, village worship associations regularly claimed authority in a wide range of activities in local life, including farming, sericulture, mining, lumbering, gambling, begging, funerals, and proper family conduct. They elaborated their procedures of assembly and deliberation and, asserting supremacy over competing channels of village authority, issued rules on how the government's village officers should be selected. In what may be considered a confirmation of the self-governing powers the village worship association had acquired in Zezhou, the Qing government, from the late eighteenth century on, gradually abandoned the lijia 里甲system and turned to village worship associations for carrying out many of its tasks (215-30).

\section{LINEAGE ORGANIZATIONS}

In Huizhou, by contrast, the village worship association's institutional dominance ended in the mid-Ming because of the rise of the corporate lineage. Some of the core ideas and practices of the corporate lineage apparently had an origin in Song times, just like the village worship association, but the development of the corporate lineage followed a very different path.

If the formation of the village worship association was driven, above all, by religious faith and the efforts of the commoners, the evolution of kinship institutions in the Song dynasty was promoted mainly by the gentry and motivated primarily by social and economic concerns: "a fear 
of the disaster of inequality" within the descent group and the persistent pressure of downward mobility resulting from the privatization of land after the mid-eighth century and the age-old practice of equitable partible inheritance (McDermott, 109, 149). The solution was to establish some form of shared property within a large kinship group beyond the household level. McDermott compares two distinct models of managing shared property and organizing large kinship groups, shaped both by the perennial dilemma between limited resources and growing membership and by new economic and social conditions from the Song period. The dominant type of large kinship organization until the eleventh century had been the large communal family ( $y i h u$ 義戶), which required all its members to have proximate — if not shared-residence and that their "dining, education, and other social activities were to be communal and tightly regulated." It was, therefore, "a selfcontained community," which required its members to completely "surrender their private property and much of their social autonomy to rule by a senior figure" and in return promised physical and material security. It also valued economic equality over productivity and focused on the retention of labor. All these features bespoke its origin in the wake of the collapse of the Han dynasty and its flourishing in the dying years of the Tang (117-19). As time progressed, however, sustained peace made physical security less of a concern; in Song times, civil service and other opportunities required successful members of the family to be more mobile, and the extension of arable land became more important than the retention of labor in the increasingly crowded countryside of southeast China. In 1050, Fan Zhongyan proposed a new approach to the management of shared property in response to these new social and economic conditions. His proposal was to establish a charitable estate (yizhuang 義莊)—or “lineage trust," as McDermott terms it—as a separate property-holding unit without requiring comprehensive control over its beneficiaries' private wealth, residence, and other social activities. By separating the corporate property from the private and refocusing its activity from the retention of labor to the management of a corporate estate, the trust thus provided a loose and inclusive framework that "limited its members' claims on the trust's property" and simultaneously limited the trust's claims on its members. Despite their fairly insignificant number in the Song and Yuan dynasties, McDermott argues that it was the lineage-trust model of kinship-based shared property management that gradually gained popularity in south China from the late twelfth century onward $(114-15,118)$. He shows, for example, that the lure of the large communal family faded for the Wangs of Wukou and their relations in the midtwelfth century and for the Jins of Xiadong in the mid-thirteenth century. The Wangs constituted a large communal family which had broken up in 1024. In 1158, when a member of an offshoot branch attempted to strengthen ties within his kinsmen, it was Fan's model that he decided to follow (140-58).

With some hindsight, Fan Zhongyan's model of a land trust is typically viewed as a precursor to the trust-based lineages of Ming and Qing times. But two important differences are worth noting. First, Fan's goal was fairly limited and that of some of his followers even less grand (146). Their concerns were primarily economic. The mission of Fan's trust was to provide "its members with no more than a portion of their food and clothing needs, of their funeral and wedding costs, and of their other living expenses, and it devolved most decisions about their daily life onto their separate branch, segment, or household units" (118). While Fan had offered these benefits to all his kinsmen, as time progressed, some trusts limited their goal to no more than ensuring the basic subsistence of their poor members in order to maintain the balance between membership numbers and resource supplies (146). As McDermott points out, Fan's rules allowed most members to escape "with no specified obligation other than to be educated and to attend certain annual performances of ancestral worship, if even that" (120). They expressed little concern for ritual practices or any other extraeconomic ties that could unite the trust's members into a tightly organized group. Conversely, Fan's heirs continued to have Buddhist monks look after their ancestors' graves and chapel (122).

In fact, ritual practices central to the development of a trust-based lineage after mid-Ming continued to be ignored or deemed inappropriate in Song times. Collective ancestral worship in the 
Song and Yuan Huizhou and elsewhere was usually performed at the graveside by small groups of kinsmen, roughly the size of a traditional mourning group ( wufu 五服), who visited the graves of the Prime Ancestor and the four immediately preceding generations at seasonal occasions (99). Worshipping ancestors in a detached building attracted few officials and was off-limits to ordinary families without official rank. Even Zhu Xi reserved the practice as a privilege of scholars and officials and, still more or less following canonical requirements, limited the worship to the Prime Ancestor and a person's four immediately preceding generations. In Huizhou, McDermott points out, merely four ancestral halls in the Song and eleven in the Yuan are recorded (103).

Second, those who were attracted by Fan's model and established land trusts for their kin were typically members of the gentry, men who had a Confucian education and often held office. ${ }^{63}$ Therefore, the growing popularity of lineage trusts in the Song and Yuan bespoke more the gentry's interest in strengthening ties in a large kinship group than a new kinship orientation in broader segments of society. Gentry families after the eleventh century also showed an interest in uniting same-surname groups on the basis of a putative First Settler or Prime Ancestor. The different Li groups in Sichuan, for example, compared their genealogies in the twelfth century and tried to reconcile conflicting accounts of their ancestral origin in the belief that they were actually descended from a common ancestor. Since the settlements of these Li groups, however, were so dispersed geographically_often in different prefectures and sometimes different circuits-and the effort to unite their genealogies seems to have concerned only literati families, these moves probably expressed the elite's desire for networking and were thus quite different from the widespread Ming trend for same-surname groups to merge into a single organized lineage. ${ }^{64}$ Recent scholarship on genealogy-writing and ancestral halls leads to similar conclusions. Patricia Ebrey and Robert Hymes both trace genealogies of the late imperial style back to the Southern Song. But they also argue that genealogy writing in the Southern Song and Yuan was mainly a practice of the literati and officials, who used it to establish social status and build political alliances as well as to provide practical information on who participated in graveside ancestral worships and where. ${ }^{65}$ In Huizhou, a text from no earlier than the Yuan and quite possibly the mid-Ming reports that "the poor and the rich or titled in his lineage participated in separate performances of ancestral worship rites" (McDermott, 106). ${ }^{66}$ In his case study of Fujian, Michael Szonyi argues that until the mid-Ming ancestral halls were constructed mainly by the gentry and descendants of prominent officials as a marker of their social status which set them apart from the rest of local society. They "stress exclusivity not commonality." 67

McDermott's detailed account of lineage rites and property in the Song and Yuan reveals how reluctant the gentry was to build a detached building for ancestral worship (100-103) and how frequently the gentry efforts of setting up a lineage trust failed in just two or three generations (13358). The development of trust-based lineages in the Ming, by contrast, was driven by a different

\footnotetext{
${ }^{63}$ Wang Shanjun 王善軍, Songdai zongzu he zongzu zhidu yanjiu 宋代宗族和宗族制度研究 (Shijiazhuang: Hebei jiaoyu chubanshe, 2000), 64-68; Linda K. Walton, "Kinship, Marriage and Status in Sung China," Journal of Asian History, 18.1 (1984), 35-77.

${ }^{64}$ Song Chen, "Managing the Territories from Afar," 292-98.

${ }^{65}$ Ebrey, "The Early Stages in the Development of Descent Group Organization," 44-49. Hymes, Statesmen and Gentlemen, 114-31.

${ }^{66}$ The text I refer to is Xin'an dazu zhi 新安大族志, conventionally attributed to a Yuan dynasty author, Chen Li 陳櫟. For an argument of Xin'an dazu zhi as a sixteenth century compilation, see Zheng Limin 鄭 力民, “Xin'an dazu zhi kaobian: Jian tan Shilu Xin'an shijia” 《新安大族志》考辨——兼談《實錄新安 世家》, Anhui shixue 安徽史學 1993.3, 24-29; “Xin'an dazu zhi kaobian: Jian tan Shilu Xin'an shijia (xu)” 《新安大族志》考辨——兼談《實錄新安世家》(續), Anhui shixue 1994.3, 14-18.

${ }^{67}$ Michael Szonyi, Practicing Kinship: Lineage and Descent in Late Imperial China (Stanford: Stanford University Press, 2002), 97.
} 


\section{Song Chen}

social group and a different constellation of social forces. Since the 1990s, a community of scholars, known to some as the "South China School" (Huanan xuepai 華南學派), have adopted a distinctive methodology in studying late imperial and modern China, which combines conventional historical research and fieldwork and draws attention to how written records were produced and used in the local setting. Focusing primarily on Guangdong and Fujian, these scholars-Zheng Zhenman, David Faure, and Michael Szonyi in particular-refute the "trickle down" theory that attributes the widespread growth of lineages in the late imperial period to the influence of Confucian discourses and elite model of proper behavior. Instead, they view lineage organization as a result of strategic attempts by local people, including many commoner families, who appropriated state-sponsored discourses and flexibly interpreted them to meet their own needs. ${ }^{68}$ Oftentimes the formation of a lineage began with registering land as a corporate trust under a single progenitor in order to fulfill and limit the descent group's shared military and fiscal obligations to the Ming state or to keep inalienable assets under collective ownership. Starting from the early sixteenth century, when ancestral halls spread through local society as a popular place to perform sacrifices, these corporate trusts were welded to these halls, transforming them into powerful property-holding institutions. These ancestral halls, unlike the gentry ones of earlier times, were "built not by members of the educated elite alone but by individuals from a wider spectrum of local elites, including merchants, moneylenders, and large landowners who did not necessarily hold degrees." They stressed inclusivity, underwrote the elite's local leadership, and served as an "instrument for the social regulation through ritual of one's kin." ${ }^{69}$ The rituals performed in these halls also deviated frequently from canonical requirements and incorporated many preexisting local religious practices. ${ }^{70} \mathrm{In}$ sum, the spread of lineage institutions in the Ming and Qing - the establishment of lineage trusts and the building of ancestral halls alike-was shaped mainly by local and non-gentry forces, rather than by the visions and deliberate efforts of the educated elite or the state. In Huizhou, as McDermott also notes, the commoners' right to build an ancestral hall was recognized only ex post facto by the court, a generation later (178-79). These findings have complicated the relationship between the Song kinship practices and the Ming-Qing lineage organizations. Rather than viewing the Song kinship-based estates and genealogy writing as the direct precursor of Ming-Qing lineage institutions, they suggest that all the Song provided was a set of ideas and experiments on kinship-based landed estates which would have never become a reality had they not been triggered by a confluence of social and political conditions in the Ming.

McDermott's study of Huizhou supplies plentiful evidence that corroborates this view. The development of lineage institutions in Huizhou began in the first half of the fifteenth century not with compiling genealogies or building ancestral halls, but with the founding of landed trusts modeled on Fan Zhongyan's charitable estate. These landed trusts were set up by rich and ambitious local men who often boasted military training or experience but had no office or degree $(8,235)$. The Doushan 竇山 trust of the Cheng lineage in Shanhe district, to which McDermott devotes half of his book, was formally established in the mid-fifteenth century by a grandson of a retired Ming general. He was a "local boss," but the basis of his social position was "not an official degree, title, or post," but "his local wealth and his family's military past." His decision to establish the trust was evidently prompted by the family's registration as a military household (junhu 軍戶), which entailed a permanent obligation to provide military service to the Ming dynasty (245-47). The construction of ancestral halls did not concern the Chengs-or the Huizhou families in general-until at least the end of the fifteenth century, when they began to explore more

\footnotetext{
${ }^{68}$ Szonyi, Practicing Kinship. Faure, Emperor and Ancestor. Zheng Zhenman 鄭振滿, Ming Qing Fujian jiazu zuzhi yu shehui bianqian 明清福建家族組織與社會變遷 (Changsha: Hunan jiaoyu chubanshe, 1992).

${ }^{69}$ Szonyi, Practicing Kinship, 113, 127-28.

${ }^{70}$ Szonyi, Practicing Kinship, 138-68.
} 
commercial uses of their collective properties and tried to enforce stricter observance of ancestral rites $(107,179,245,306)$.

Thus, unlike the village worship association in Zezhou, which began as a ritual organization and acquired corporate property later on, the lineage formed first as a property-holding unit and then took on ritual activities. But these two institutions resembled each other in one way: at a later stage of their development, they both claimed sanctioning powers and evolved into a form of self-government in the countryside. For lineages in Huizhou, the opportunity presented itself in 1567 when the Huizhou government decided to have community pacts "set up on the basis of already existing lineage organizations ( $z u$ 族) or subdistrict administrative units ( $t u$ 圖)," instead of village worship associations (McDermott, 196). Lineages and their leaders, as McDermott has demonstrated in an earlier article, seized this opportunity and used community pacts (xiangyue 鄉約) to bolster their own power. Community pacts have a long history dating back to the Song dynasty Neo-Confucian scholars Lü Dajun 呂大鈞 (1031-82) and Zhu Xi 朱喜 (1130-1200). "Whereas Lü sought to create a mutual aid organization for village commoners" with his community pact, McDermott argues, "Zhu was more anxious to stress the central role of scholars in rural life and emphasized the moral, at least as much as the material, well-being of Chinese villagers" by inserting much more etiquette and ceremony into his redaction of Lü's pact. The community pact received little attention from the Ming court and its officials, at least after the death of its founding emperor in 1398. But starting from the late fifteenth century, there was a revived interest among local officials in the community pact as a way of imposing control and restoring order in the countryside. These officially drafted and promoted community pacts, often drawing on the ideas of Wang Yangming 王陽明 (1472-1529) and Wang Tingxiang 王廷相 (1474-1544), differed from the Song texts by "giving a larger role to the state as initiator and implementer of their rules" but had limited success in their implementation. But local officials' backing of community pacts opened the door for their adoption in the lineages. ${ }^{71}$

From the mid-sixteenth century on, as McDermott and a modern Chinese scholar have observed, community pacts were "initiated, enforced, and led by gentry and elders" in many lineages across South China. The rules of these pacts, in contrast to the officially drafted versions, were in fact, no different from family rules—referred to variously as cigui 祠規 or jiafa 家法 among other termsthat also began to proliferate. As the title of one such text from Huizhou- "The Community Pact and Family Rules of Wentang” (Wentang Chenshi xiangyue jiafa 文堂陳氏鄉約家法)—suggests, they were considered one and the same. These pacts and rules "stressed filial piety to the lineage and largely ignored the demands of the state." To enforce them, lineages set up their own structure of authority, including, for example, positions of pact heads (yuezheng 約正), pact assistants (yuefu 約副), prosecutors (sisong 司訟), and pickets (sijiu 司糾). ${ }^{72}$

With the implementation of these pacts and rules, lineage leaders sought to restrict the government's role in lineage affairs. Taxes were discussed in the lineage's monthly meetings to ensure that they would be paid on time and not become an excuse for government interference. They required that all conflicts within the lineage be handled by household heads, pact heads, and deputies, and discouraged their members from filing lawsuits in government courts. They strictly barred the state from interfering in the lineage's management of its own human and material resources, such as late payments of rent, robberies, and general unrest. ${ }^{73}$ The developments in the mid-sixteenth century,

\footnotetext{
${ }^{71}$ Joseph P. McDermott, "Emperor, Élites, and Commoners: The Community Pact Ritual of the Late Ming," in State and Court Ritual in China, edited by Joseph P. McDermott (Cambridge: Cambridge University Press, 1999), 300.

${ }^{72}$ McDermott, “Emperor, Élites, and Commoners,” 317; Chang Jianhua 常建華, Mingdai zongzu yanjiu 明 代宗族研究 (Shanghai: Shanghai renmin chubanshe, 2005), 265.

${ }^{73}$ McDermott, "Emperor, Élites, and Commoners," 328.
} 


\section{Song Chen}

therefore, transformed the lineage from a trust-based group of shared economic interests into a tightly organized self-governing body that was capable of exercising a wide range of sanctioning powers.

One may ask why the Huizhou government turned away from the village worship association to the lineage as the organizational interface between the state and local residents. The short answer is that by the mid-sixteenth century, the lineage — not the village worship association-had become the dominant village institution in Huizhou. This dominance was hard won. And McDermott has painstakingly reconstructed the lengthy and contentious process through which the lineage rose to predominance at the expense of its institutional rivals: Buddhist establishments and village worship associations. As has been discussed, Buddhist establishments had, for many centuries, owned farmland and forests, engaged in moneylending, and looked after ancestral graves for local families. Village worship associations that had developed in Song times, on the other hand, provided an inclusive form of village organization based on territorial affiliation and the building blocks for an extensive network between villages. Situating his study in this wide institutional context, McDermott shows that over the fifteenth and early sixteenth centuries, individual village worship associations "had commonly, though not universally, fallen under the domination of a single lineage," which restricted association membership to its own kin and forced out non-kin members. In the meantime, lineages also aggressively replaced village worship associations as the building blocks for multi-village alliances. To do so, the lineage claimed the association's tutelary deity—for example, Cheng Lingxi and Wang Hua —as its Prime Ancestor and then seized the community shrine as a lineage property, despite the Chengs' and Wangs' clearly insignificant role in the earlier history of the cults. In this regard, the widespread anthropomorphization of earth spirits since the late Tang actually paved way for this mid-Ming development (200-210). Moreover, from the latter half of the fifteenth century and usually after they had successfully seized power from the village worship associations, lineages waged protracted battles against local Buddhist establishments. By the late sixteenth century, many larger Huizhou lineages had successfully forced the monks to return land grants, ancestral graves, and their surrounding structures to the descendants of their benefactors, thus transforming chapel lands into lineage trusts. Thus, over the first two centuries of Ming rule, there was "a sea change in the ranking of village institutions" (179): lineages replaced village worship associations and Buddhist temples as the dominant institution in rural Huizhou, descent ties replaced territorial affiliation as the dominant principle of rural organization, and many of Huizhou's villages became single-lineage villages where a single kinship group had achieved organizational dominance. The 1597 decision of the Huizhou government, therefore, was a recognition of the lineage's victory after two centuries of battle.

This trajectory of the lineage's rise to organizational dominance was not unique to Huizhou. Local residents in Leizhou 雷州, Guangdong, had worshipped a "thunder ancestor" (Leizu 雷 祖) as the rain god in the Tang. Usually portrayed as a grotesque-looking, beast-like creature, with horns and wings, the thunder ancestor began to be identified by the early eleventh century as a certain Chen Wenyu 陳文玉, a putative native of Leizhou who had passed the civil service examinations and carved out a successful bureaucratic career. No later than the mid-seventeenth century and, quite possibly, as early as the Wanli reign (1573-1620), the Chens in the villages near the shrine started claiming themselves descendants of the thunder ancestor, turned the shrine into their ancestral hall, and managed its attached fields as a lineage trust. Likewise, in Gaozhou 高州, Guangdong, the Fengs 馮 in Old City village started organizing their kinsmen into a tighter kinship group in the early seventeenth century and by mid-Qing they had constructed a story tracing their descent to Lady Xian (Xian furen 冼夫人), focus of a local cult and wife of a certain Feng Bao 馮寶, and made Lady Xian's shrine in the Old City village, as opposed to the Fengs' ancestral hall, the focus of their seasonal offerings. ${ }^{74}$

\footnotetext{
${ }^{74} \mathrm{He} \mathrm{Xi}$ 賀喜, Yi shen yi zu: Yue xinan xinyang goujian de shehuishi 亦神亦祖：粤西南信仰構建的社會 史 (Beijing: Sanlian shudian, 2011), 96-136, 175.
} 
The victory of the lineage over its rivals was never absolute. In Leizhou, another Chen group in Bangshan 傍山 village lost a lawsuit as late as 1784 when they tried to claim a nearby shrine dedicated to the thunder ancestor as their ancestral hall and the shrine's attached fields as their lineage property. In Gaozhou, over the course of the Qing, Lady Xian's shrine in the prefectural seat continued to be maintained and its attached fields owned by a multi-surname worship organization. ${ }^{75}$ In some places like Zezhou, corporate lineages never fully developed. There, as Du's account makes clear, efforts to bind kin into a more tightly organized group centered on a free-standing ancestral hall and a landed trust surfaced after the mid-sixteenth century, but they reflected no more than the ideals of individual gentry figures and received little support. The lineages those individuals established usually had a weak organizational structure, possessed minimal collective property, and rarely survived the death of their founder. Throughout the Ming-Qing period, ancestral worship in Zezhou was typically performed at the graveside. Genealogy writing and ritual preparations were placed under the charge of a "gravesite sacrifice association" (musihui 墓祀會) or an “ancestral worship association” (zuzonghui 祖宗會). By contrast, it was the village worship association dating from the Song times that continued to provide an effective means of local organization all the way into the Qing. Even single-surname villages participated in public affairs in the form of village worship associations rather than lineages (Du, 192-96).

It is also important to note that even in places like Huizhou and Fujian where lineage organizations were more developed, shared religious symbols and common worship activities remained a powerful mechanism of local organization. In Huizhou, even after individual village worship associations each fell under the domination of a single lineage, the lineage and the village worship association remained conceptually different and each lineage typically maintained both an ancestral hall and an association hall (shewu 社屋). Whereas the ancestral hall was for the "master of the clan" (jiazhu 家主), the association hall was dedicated to the "master of the village" (cunzhu 村主). Supra-village religious symbols (e.g., those in the Shuanglie Shrine 雙烈廟) and the joint performance of worship rites continued to create a ritual space jointly participated in by different surname groups living in different villages, each representing themselves with the tutelary gods it had sheltered in its association hall. Likewise, in a multi-surname village, common worship of the same tutelary gods (e.g., those in the Cundi Shrine 準提廟) continued to provide an organizing node for different descent groups in the village, each of which may have had its own lineage hall and lineage-sponsored association hall. ${ }^{76}$ Similarly, on the basis of their extensive fieldwork on the Putian plains in Fujian, Kenneth Dean and Zheng Zhenman have argued that a "nested hierarchy of temples" continued to demarcate both village-level and multi-village communities, even though the organization of religious activities in some single-surname villages was based on branches of the lineage. ${ }^{77}$

Thus, from the Song to mid-Qing, local society became increasingly organized around resourcerich and tightly organized social institutions, first based on territorial affiliation and shared religious symbols and then also on claims of common ancestry. Over the course of the Ming and Qing, these institutions evolved into property-holding corporate entities with elaborate organizational

\footnotetext{
${ }^{75} \mathrm{He}, \mathrm{Yi}$ shen yi zu, 138, 183.

${ }^{76}$ Zheng Limin 鄭力民, “Huizhou shewu de zhu cemian: Yi She nan Xiaonü hui tianye ge' an weili” 徽州社 屋的諸側面——以撮南孝女會田野個案為例, Jiang Huai luntan 江淮論壇 1995.4, 70-75; "Huizhou shewu de zhu cemian: Yi She nan Xiaonü hui tianye ge'an weili (xu)" 徽州社屋的諸側面——以歌南孝 女會田野個案為例 (續), Jiang Huai luntan 1995.5, 78-79.

${ }^{77}$ Kenneth Dean, "Transformation of the She (altars of the soil) in Fujian," Cahiers d'Extrême-Asie, 10 (1998), 29-30, 56. See also Zheng Zhenman 鄭振滿, “Shenmiao jidian yu shequ fazhan moshi: Putian Jiangkou pingyuan de lizheng” 神廟祭典與社區發展模式——莆田江口平原的例證, in Xiangzu yu guojia: Duoyuan shiye zhong de Min Tai chuantong shehui 鄉族與國家——多元視野中的閩臺傳統社會 (Beijing: Sanlian shudian, 2009), 224-33.
} 


\section{Song Chen}

structures and possessing sanctioning powers over their members. These institutions provided organizational frameworks in local society that competed, intersected, as well as collaborated with each other. It is evident-in particular, from our discussion of the lineage's phenomenal success in Huizhou and the gentry's failure to replicate it in Zezhou-that the rise of these social institutions was driven mainly by local forces, rather than resulting from government mandate or successful promotion by the educated elite. In contrast to the gentry, whose privileged local status depended heavily on degrees and official titles awarded by the state, leaders of these institutions derived their power from the economic and organizational resources they controlled. These two sources of power and, correspondingly, the two types of local elites are useful analytical constructs for articulating patterns of change in local society after the Song dynasty. In reality, however, and especially from the late Ming on, the boundaries between these two realms were blurred.

THE GENTRY, LOCAL INSTITUTIONS, AND LOCAL ELITE ACTIVISM IN THE MING AND QING

As lineages and village worship associations evolved into powerful social institutions with substantial material and organizational resources in the Ming and Qing, they provided the institutional underpinnings for their leaders to take on a more active role in local society. The leadership in neither type of these institutions was constituted exclusively by men of gentry status, but the role of gentry figures in these institutions was always prominent from the Ming on.

In the weakest form, the gentry participated actively in the affairs of these institutions and cooperated with them. In the absence of powerful lineage organizations, the village worship association was an indispensable means of marshalling local resources, organizing public projects, and promoting community solidarity in late imperial Zezhou. Even gentry leaders who were troubled by religious festivals dedicated to the local tutelary deity recognized the strength of the village worship association in these areas. Some gentry families (e.g., the Chens of Guoyu) did distance themselves from the local worship association, but many others (e.g., the Zhangs from the same town) participated actively in its affairs and joined the community's religious assemblies (hui 會) and festivals (saishe 賽社). Evidence from the mid-seventeenth century shows that gentry leaders who proposed a local project consulted the leaders of village worship associations and relied on their financial and organizational resources ( $\mathrm{Du}, 265)$. The relationship between the gentry and corporate lineages could be even closer. Gentry families had long recognized that perpetuating their political status and solidifying their local power base were mutually reinforcing. Kinsmen with gentry status provided political protection for lineage interests, whereas a lineage with abundant material resources, in turn, could afford superior educational facilities for their members, increase their odds of success in the examinations, and thereby improve the chance of perpetuating their gentry status. ${ }^{78}$ As McDermott has pointed out, from very early on, aspirant members of the Chengs-those in the third branch-pursued a two-pronged strategy of "maintaining official representation in government and a consistently strong leadership at home" (291). They pushed their descendants towards official careers, but chose one from their ranks, who usually had no degree whatsoever, as the resident manager of the lineage's trust (356). Thus, although men holding advanced degrees and offices were usually posted away from home and rarely involved directly in the management of lineage trusts, their connections with these trusts were far from inconsequential.

Indeed, the relationship between the gentry and local institutions often went beyond strategic accommodation and cooperation for mutual benefits. Descent groups that had great success in the examinations and government enjoyed a competitive edge that made them more likely than

\footnotetext{
${ }^{78}$ Elman, A Cultural History of Civil Examinations in Late Imperial China, 246.
} 
others to dominate a lineage or village worship association. Their competitive edge was both demographic and sociopolitical. Du shows, for example, that the Yuans 原, which claimed the majority of positions in the managerial corps of Xiajiao 下交 village's worship association, not only produced a considerable number of degree holders and high-ranking officials, but also had a much larger population than other surname groups in the village (164). McDermott observes a similar phenomenon in his discussion of the Doushan trust of the Shanhe Chengs. After the death of its founder in 1454, the trust was, in theory, placed under shared management of its five constituent branches, but in practice almost always dominated by the lineage's third branch, which enjoyed consistent success in the civil service examinations and, at the same time, expanded demographically at a much faster pace than other branches in the lineage. Examination success, as McDermott puts it, was "virtually essential for the flourishing of any large lineage and the dominance of any of its branches from the middle of the fifteenth century onward" (260-61).

From the sixteenth century on, the distinction between local power derived from state-certified status and that from institutional leadership became even more blurry, as men of gentry status and the leaders of local institutions began to overlap significantly. This development resulted, in particular, from the growing ranks of men holding lower-ranked degrees, such as district school and Imperial University studentships. These degrees became easier to obtain after 1537, when the Ming court made some of them available for purchase to all who could afford them, further deepening the mutual infiltration between the gentry and the local commercial elite. ${ }^{79}$ These degrees, which rarely led to examination success at higher levels or official assignments, were essentially markers of status which not only exempted their holders from onerous labor service duties but also certified their membership in the local gentry. In the Doushan trust, for example, the relationship between gentry status and lineage leadership became all the more intimate-and the third branch's dominance all the more absolute-after the late sixteenth century when the Doushan trust fell under the control of the "Culture Group" (siwen 斯文), which was constituted exclusively by men holding at least—and usually only-lower-ranked degrees (McDermott, 356). Although the adoption of an examination degree as a requisite condition for lineage leadership served the third branch well in its competition with other branches, arguably it also reflected a general recognition that having degree-holding leaders represent the lineage would allow for more effective negotiations with the local government. Likewise, in Zezhou, men with low-ranked degrees, like Licentiate Zhang Duoxue 張多學 in Guoyu, evinced no interest in a bureaucratic career but instead served as a manager of an association (sheshou 社首) for many years (Du, 130, 139). Wealthy merchants such as Wang Chongxin 王重新, who made generous donations to local projects and became an association manager, purchased low-ranked degrees and urged his sons to study for the examinations ( $\mathrm{Du}, 141-42)$. Unlike the Doushan trust, however, examination degrees seem never to have been a requirement for leadership in a village worship association. $^{80}$

In some places, the gentry could be far more aggressive. In the mid-Qing Foshan, for example, gentry leaders established their own corporate institution and expanded its power at the expense of existing local institutions. In the mid-sixteenth century, the only recognizable collective body in Foshan was the Eight Tu (batu 八圖), a management structure of town affairs derived from the old lijia institutions and centered on collective worship of the Northern Emperor in the Beidi Temple. Not surprisingly, the property of the temple constituted the largest existing source of wealth for public purposes in the town and was under the control of the Eight Tu. In the closing

\footnotetext{
${ }^{79}$ William T. Rowe, review of The Making of a New Rural Order in South China: I. Village, Land, and Lineage in Huizhou, 900-1600, by Joseph P. McDermott, The Journal of Asian Studies 75.3 (2016), 817.

${ }^{80}$ Kenneth Dean also supplies evidence of the local gentry taking charge of a village worship association's affairs on Putian plains of Fujian. Dean, "Transformation of the She (altars of the soil) in Fujian," 51.
} 


\section{Song Chen}

years of the Ming, however, the gentry of Foshan began to have a stronger presence in the town. With donations, they revived a defunct local school in 1624 and erected a meeting hall (huiguan 會 館) for themselves three years later. The establishment of the meeting hall, later known as Dakui Hall (Dakui tang 大鬼堂), signaled the gentry's independence from the Beidi Temple, where they had previously held meetings, and began to give the gentry network the look of a formal organization. The gentry's relationship to the Beidi Temple came full circle a century later, when they successfully forced the Eight Tu to relinquish its special rights to the temple and its attached property and thus relegated it to a purely ritual organization. A "watershed in town affairs," as Mary Buckus Rankin calls it, this victory gave the gentry access to the considerable income of the temple as well as to its symbolic capital. Almost at the same time, a petition was sent to the magistrate in the name of "all gentry leaders of the town," contesting the Huo lineage's claims on the property at Foshan's main wharf. The petition was resolved, again, in the gentry's favor, confirming-if not establishing - that shops and other structures at the wharf were the town's collective property. These developments in the mid-eighteenth century gave the increasingly powerful gentry establishment access to lucrative sources of revenue for financing community projects they favored, including a charitable school in 1744 and a community granary in 1795, among others. The Dakui Hall became a core institution in Foshan, providing an organizational structure for gentry leadership, with its own managers, and a forum for deliberation of town affairs and negotiation between the gentry and other local interests. It also managed public funds, organized public projects, and supervised the operation of the charitable granary and other local institutions. ${ }^{81}$

Thus, several centuries of institutional evolution provided the gentry in Ming and Qing times with enormous tangible and intangible resources that allowed them to take on a more active role in local society than their Song and Yuan predecessors. These changes stood out most clearly when one compares privately organized local defense in the Southern Song, the late Ming, and the mid-nineteenth century. In the Southern Song, private militias were few and relied heavily on the leadership and resources of individual families. In much of Fuzhou, as Robert Hymes has observed, "no indigenous, effective, permanent, private force emerged" throughout the Southern Song. The elite's involvement in local defense was usually sporadic and provisional, mainly in response to immediate dangers of local disorder, and each militia's activity was "strongly localized within [its leader's] own county or the area around his residence." The only enduring militia organization was the "Two Societies of the Dengs and Fus" (Deng Fu ershe 鄧傅二社) of Jinxi county, which seems to have survived from 1127 at least to 1261 and, at times, operated in several counties of the prefecture. But, as its name suggests, the Two Societies was largely a "cooperative enterprise" of two prominent local families. It was an association of two militia units organized by the Dengs and Fus respectively, each of whom built and manned a private fort close to home and disbursed their family's wealth to hire militiamen from local families living nearby but usually having different surnames. Both the overall leadership of the Two Societies and the commandership of each constituent unit were expected to pass on from father to son within the same family. ${ }^{82}$ In Mingzhou, too, there was only one sure case of privately organized local militia in

\footnotetext{
${ }^{81}$ Mary Buckus Rankin, "Managed by the People: Officials, Gentry, and the Foshan Charitable Granary, 1795-1845," Late Imperial China, 15.2 (1994), 1-52, especially 8-17; David Faure, "What Made Foshan a Town? The Evolution of Rural-Urban Identities in Ming-Qing China," Late Imperial China 11.2 (1990), 1-31.

${ }^{82}$ For a brief period in the early Southern Song, the overall leadership seems to have been entrusted to a member of the Lus, a large communal family in the county which had by then produced two jinshi and been in-laws with the Dengs for generations, but by the early thirteenth century, if not earlier, the Lus' ties to the Two Societies dissolved and the overall leadership ended up in the hands of the Deng family. Hymes, Statesmen and Gentlemen, 139-50.
} 
the Southern Song, which was led and funded by the Li family and seems to have been no more than a provisional response to the Jurchen invasions (Lee, 88). ${ }^{83}$

In late Ming Shanxi, worship associations in some market towns began to take on a prominent role in organizing local defense. The construction of the Guoyu and Diji 砥洎 forts was a case in point. Although gentry figures reputedly advocated - and even boldly claimed full credit for - the construction of these forts, the projects were obviously funded and organized by worship associations in these towns and the forts considered a collective property of the townspeople ( $\mathrm{Du}$, 143-46, 150-52). Admittedly, village or town worship associations did not always play an active role in late Ming local defense. In much of late Ming Shanxi, local defense continued to rely on whatever resources individual families could provide, just as in the Southern Song, and typically protected no more than an individual village or market town with little sign of higher-level coordination. Even many expensive projects, including the construction of fortified structures, were funded by the private wealth of individual families and manned by their retainers (jiading 家丁). Since lineage organizations never developed fully in this area, sometimes even pooling resources from a larger kinship group beyond the household level was not feasible.

This contrasted markedly with the mid-nineteenth century when non-governmental local institutions had evolved into property-holding corporate entities with coercive power and provided enormous material and organizational support that shored up gentry activism. First, the proliferation of lineages and village worship associations provided gentry leaders with a ready means of social organization and mobilization. In the mid-nineteenth century, local defense systems often grew out of existing lineage and village organizations, often by superposing an added layer atop these organizations to coordinate activities and pool resources from a vast area. Near Guangzhou, during the summer of 1841, just after the incident at Sanyuanli 三元里, the gentry quickly organized a well-ordered militia by constructing a new "community school" (shexue 社學) which served as a headquarters for twelve or thirteen multi-village alliances in surrounding market towns, which in turn coordinated a total of more than eighty villages. ${ }^{84}$ These villages and multi-village alliances, however, were more than loosely articulated, informal frameworks of gentry cooperation, as was once surmised. Instead, a recent study of the nearby East Mountain community suggests that they were more inclusive village or supra-village associations based on common residence and collective worship, though they may have come under the domination of powerful gentry lineages by the mid-nineteenth century. ${ }^{85}$ In Hunan, the lineage was the basic

\footnotetext{
${ }^{83}$ In contrast, Huang Kuan-chung's study shows that the most formidable private armies in the early Southern Song were led and funded by tea smugglers. Huang Kuan-chung 黃寬重, Nan Song difang wuli: Difang jun yu minjian ziwei wuli de tantao 南宋地方武力——地方軍與民間自衛武力的探討 (Taibei: Dongda tushu gongsi, 2002), 239-74.

${ }^{84}$ Philip A. Kuhn, Rebellion and Its Enemies in Late Imperial China: Militarization and Social Structure, 1796-1864 (Cambridge, Mass.: Harvard University Press), 69-72.

${ }^{85}$ In this case, it was the xiang 鄉 or yue 約 that denoted village-wide worship communities, whereas the term she 社 referred to, quite confusingly, multi-village alliances centered on a common tutelary god. The East Mountain community, known as Dongshan she 東山社, was one such multi-village alliance centered on the Northern Emperor cult, which seems to have been dominated by the $\mathrm{Wu}$ 䣕 lineage since the mid-eighteenth century. It was constituted by seven (later nine) villages (xiang 鄉 or yue 約), each protected by its own tutelary god commonly referred to as the "village lord bodhisattva" (cunzhu pusa 村主菩薩). In the mid-nineteenth century, the East Mountain community delimited the natural boundary for a local militia with the Wus as its natural leaders. Some 35,000 militiamen were recruited from its constituent villages and funded by several different sources of revenues, all led and managed by prominent figures from the Wus. Zhu Guangwen 朱光文, "Shemiao yanbian, cunji lianmeng yu yingshen saihui: Yi Qing yilai Guangzhou fu Fanyu xian Jiaotang si Dongshan she wei li” 社廟演變、村際聯盟與迎神賽會——以清以來廣州府番禺縣荠塘司東山社為例, Wenhua yichan 文化遺產 2016.3, 113-16. Du's account of the Shuidong community provides another
} 


\section{Song Chen}

unit from which militia were raised and organized, and these autonomous lineage militia forces were then aggregated and placed under the leadership of gentry figures who were bound by teacher-disciple ties and classmate bonds. ${ }^{86}$

Second, the rise of various types of corporate institutions also provided gentry figures with convenient access to a vast body of economic resources, including not only profits from these institutions' collective property but also revenues they could requisition with their private taxing powers. In a more abstract sense, several centuries of institutional evolution and economic progress provided the gentry in the mid-nineteenth century with a complicated toolkit of financial management: the very idea of setting up a corporate organization to manage collective property and finance local initiatives, the gentry's experience in managing these organizations and negotiating with the government on their behalf, and the widely accepted practice for these organizations to exercise private taxing (tax-farming) powers. It then causes no surprise that gentry figures moved swiftly in the mid-nineteenth century along these lines. Their typical course of action in funding local defense was to establish a corporate institution (often in the name of a literary society [wenshe 文社], public office [gongju 公局], militia bureau [tuanlian ju 團練局], or community school [shexue 社學]) and fund it by setting up trusts and giving it the power to impose levies. To support the Shunde 順德 militia near Guangzhou, for example, the gentry immediately set up an Azure Cloud Literary Society (Qingyun wenshe 青雲文社), to which at least several thousand $m u$ of land was attached, and a militia bureau which not only recruited militiamen but also collected a tax from the silk spinners. ${ }^{87}$ As Philip Kuhn has observed, these special taxes provided a more important source of funding for local militias in the mid-nineteenth century than personal wealth and lineage-owned resources. The taxing authority of these gentry-led institutions became "a buttress of localism" and further augmented the power of the gentry by deepening their infiltration of the taxing process as a whole. ${ }^{88}$

\section{CONCLUSION}

In an attempt to provide an analytical framework for explaining historical change that takes into account the temporal characteristics of events, Ronald Aminzade calls on scholars to "reject the notion of a single master process" and conceive long-term historical change in terms of "intersecting trajectories with independent temporalities." He defines a trajectory as "a cumulative, rather than repetitive, sequence of linked events, suggesting a certain directionality to change." The intersection of multiple trajectories, he argues, "produces key moments, or conjunctures that mark the coming together of relatively autonomous processes" and may lead to substantial structural change. ${ }^{89}$

The five books reviewed in this essay reveal that the Song marked the beginning of a major transition in history. Two trajectories, or paths, of change date back, in one way or another, to the Song dynasty. One trajectory concerns the transformation of China's social and political elite. In the ninth century, Tackett demonstrates, political power was monopolized by a capital elite, while men living in the provinces had little chance of obtaining official rank, much less rising to political prominence. More men from the provinces entered civil service following the founding of the

example of the term she being used to designate a subgroup of village worship associations in a multi-village alliance after the Ming (56-57).

${ }^{86}$ Kuhn, Rebellion and Its Enemies, 80-81, 138-39, 147-51.

${ }^{87}$ Faure, Emperor and Ancestor, 300-301.

${ }^{88}$ Kuhn, Rebellion and Its Enemies, 87-91.

${ }^{89}$ Ronald Aminzade, "Historical Sociology and Time," Sociological Methods and Research 20.4 (1992), $466-67$. 
Song, but the close relationship between capital residence and political success continued to a significant degree into the mid-eleventh century, providing strong incentives for officeholders to abandon their ancestral homes, move their families to the capital (or a place with easy access to it), and replicate the behavior of the Tang capital elite. From the mid-eleventh century onward, however, a combination of social, economic, and institutional factors significantly weakened the privileged position of the capital and offered more political opportunities to men in the provinces. As political success became increasingly detached from capital connections, the capital elite dispersed, and the new political elite was constituted by office-holding families who continued to live in their native places after gaining official rank. These families built extensive social networks at home with their social and political equals, which helped advance their careers in government and consolidate their local power at the same time. These office-holding families and many others who received the same classical education but had not yet broken into the circle of officials formed a new type of elite in local society - the gentry—whose claims of higher social standing rested on their close ties to the state and a national literati culture. Thus, from the mid-eleventh century onward, the political elite was transformed from a capital-centered group into a locally embedded group. Accordingly, the local elite was differentiated into a group who had stateawarded markers of status, such as examination degrees and official titles, and those who did not.

The other trajectory of change is the rise of local institutions, which, over time, provided the organizational framework of the countryside. The strength of these institutions derived from the corporate property, formal structure, and sanctioning powers they acquired over several centuries of evolution. But they all originated from ideas and practices that first gained popularity in Song times. Village worship associations acquired greater organizational capacity apparently because of the growth of supra-village tutelary gods in the Song dynasty and the new practice of worshipping them in shrines, rather than in the open air, which gave rise to the need for villages to marshal local resources and coordinate their activities for collective worship. Lineage organizations also began with the idea of establishing a kinship-based trust, conceived initially by the eleventhcentury scholar-official Fan Zhongyan. This idea offered an alternative approach to managing collective property and organizing a kinship group, which was increasingly favored by the gentry during the Song and Yuan over the establishment of large communal families. It became a practical model and a source of legitimacy for lineage trusts that mushroomed from the fifteenth century onward.

The concept of trajectory, with its emphasis on the sequential order of linked events, asserts the causal power of temporal connections among events and explains a particular outcome in terms of cumulative change in a long-term process. Not all choices and events in the sequence, however, are of equal import. Key choices at a given historical moment, such as those in the Song, shape subsequent paths of development by enabling, empowering, as well as constraining future options. This causal relationship among temporally connected events ensures a marked degree of continuity in the midst of change, as change unfolds in a long-term historical process. And for this reason, continuity never implies stagnation and is never established through sheer cultural or social inertia. At every moment in the process, continuity requires social action that reaffirms, reinforces, and even amplifies past choices. On the one hand, the rise of the gentry owed as much to the favorable policies of the Song as to those of later dynasties. Throughout the Song, the gentry had a limited geographical presence and existed only in a few affluent areas, mainly the ZhejiangFujian coast and the Chengdu basin. As Iiyama argues, they did not become a recognizable social stratum in much of North China until political division following the Jurchen conquest protected northerners from their well-endowed southern competitors. After the mid-fifteenth century, the gentry became a widespread social stratum across the empire, owing much to the regional quota system the Ming and Qing dynasties designed. On the other hand, the rise of local institutions arguably owed even more to developments over the course of the Ming and early Qing. As McDermott and Du have both shown, only after the sixteenth century did these local institutions develop into 
full-bodied self-governing entities. First, extra-economic ties developed in large kinship groups which had previously been bound primarily by their shared ownership in the lineage trusts, thereby transforming them into more tightly organized groups. The ancestral hall, which proliferated in the sixteenth century, was more than a site of collective ancestral worship. It served as the organizational backbone of the more tightly organized lineage, exercising not only ownership of the lineage's collective property but also supervision over its kinsfolk. Over the sixteenth century, the ancestral hall promulgated detailed and extensive codes of conduct for the kinsfolk and developed an elaborate structure of self-government with tremendous coercive powers. The lineage also reinforced the ritualistic elements in its group activities, including ancestral and communal sacrifices as well as regular lecturing on moral injunctions. ${ }^{90}$ Second, the village worship association landed in the same place from the opposite direction. Originating as a ritual organization, many village worship associations - at least those in southern Shanxi-began to evolve into a property-holding entity with more extensive responsibilities in the local community after the midsixteenth century. They developed a more elaborate organizational structure and assumed broad sanctioning powers. By the mid-eighteenth century, some associations grew fully into a form of village self-government, capable of imposing levies on the land of their members.

These two trajectories of change created two distinct sources of authority after Song times: one derived from state-awarded status markers and the attendant social networks, and the other from the domination of institutions which controlled economic and political resources in local society. Over the course of the Ming, and especially after the mid-sixteenth century, these two trajectories intersected and these two sources of authority overlapped significantly, leading to the spread of selfgoverning bodies-under gentry leadership or influence-that profoundly transformed the relationship between the state and local society. On the one hand, descent groups that enjoyed success in the examinations and produced officials expanded demographically and accrued more social and political prestige than others. They had a better chance to dominate the leadership of a lineage or village worship association or, at the very least, win the cooperation of these institutions. More aggressive members of the gentry created their own organization and funded it by seizing the resources of existing local institutions. On the other hand, with low-ranked degrees increasingly available for purchase after the sixteenth century, leaders of a lineage or village worship association not infrequently took advantage of this opportunity to attain more fiscal and legal privileges for themselves and further elevate their social status. By the mid-Qing at the latest, the gentry's combination of their state-awarded status, expansive social networks, and institutional resources under their command made them an ever more powerful group than their Southern Song predecessors, allowing them to engage more actively in local affairs than ever.

Clearly, this type of local gentry activism was not separate from the state. Not only did the gentry frequently cooperate with the state in undertaking local projects, but their expansive social networks and their ability to dominate local institutions derived, in the first place, from their privileged local status associated with their degrees and official rank. Moreover, these institutions were more than an organizational framework. As Prasenjit Duara has observed, they "acquired their special legitimating aura [precisely] because the imperial order-the state and orthodoxy-was

${ }^{90}$ As early as 1964, Zuo Yunpeng had provided a cogent discussion of how the corporate lineage evolved over time from a kinship group bound primarily by economic interests to a tightly organized, self-governing entity that exercised coercive power. See Zuo Yunpeng 左雲鵬, “Citang zuzhang zuquan de xingcheng jiqi zuoyong shishuo” 祠堂族長族權的形成及其作用試說, Lishi yanjiu 歷史研究 5-6 (1964), 97-116. A similar path of evolution is documented for lineages in Taihe, Jiangxi. See John W. Dardess, A Ming Society: T'ai-ho County, Kiangsi, in the Fourteenth to Seventeenth Centuries (Berkeley: University of California Press), 112-38. 
symbolically represented in them." ${ }^{91}$ Lineages derived their legitimacy from the Confucian ideology of ancestral worship and descent group solidarity. Village worship associations appropriated, as their religious symbols, cultural heroes in the Confucian tradition (Cheng Tang), deities patronized by the state (Jade Emperor), and gods associated with dynastic loyalty (Cheng Lingxi), and actively sought explicit imperial endorsement. Yet both lineages and village worship associations flexibly interpreted canonical requirements and the meanings of their religious symbols to meet local interests. If the rise of these local institutions may be seen, symbolically and organizationally, as a manifestation of "the integration of local society into the state," this integration was achievedas is evident in the contours of lineage development more than anything else-only by finding a way to accommodate various interests in both cultural expressions and organizational forms. ${ }^{92}$

We are left with one more question. If continuity, or a certain directionality of change, was achieved through subsequent choices made at different moments of the process, what mechanisms ensured that post-Song actors made choices that, to use the words of Aminzade, "sustain[ed] movement along the chosen path and prevent[ed] reversal or subsequent shifts to alternative possible branchings"?93 Granted, not all political and social actors after the Song always stayed on the chosen path. The Mongols, for example, decided against using the civil service examinations as the primary route of recruitment. Yet, as Iiyama argues, this decision had limited impact on later history and the mid-fifteenth century witnessed a return to the Song policies (430-32). Those choices that had lasting consequences, by contrast, were remarkably consistent in that they all contributed to the expansion of political participation, the growth of a locally rooted, educated elite with connections to the state, and the spread of self-governing local institutions.

This may have had to do with the overall social and political milieu in late imperial times, which defined cultural preferences and conferred legitimacy on a given range of decisions. More importantly, I think, these choices were consistent because they were in response to the same long-term structural changes-above all, the growth of commercial wealth - and they worked precisely because they capitalized on opportunities provided by these long-term structural changes. First, economic progress, especially the growth of commercial wealth, shored up both the emergence of gentry and the spread of local institutions from the Song dynasty onward. Southern economic progress created the danger of political fragmentation and prompted the Song dynasty to enlarge the scope of political participation, but it also allowed for steady investment in education that continued to sustain the expansion of the educated elite in the following centuries. Second, the marked growth of local institutions had an even more intimate relationship with the growth of commercial wealth. As Michael Szonyi aptly puts it, "commercial prosperity vastly increased the material resources of members of other types of rural elites, who used them to behave in a manner befitting the educated elite in the hopes of narrowing the social distance between them but with the unanticipated result that, in terms of leadership and organization, [ancestral] halls increasingly reflected the input and interests of those whose claim to elite status was based purely on wealth." 94 These ancestral halls, in turn, played a critical role in the "accumulation and distribution of investment capital in the Huizhou countryside." The lineage institution, Joseph McDermott argues, "served as a credit association." Using "these halls' construction budgets, maintenance costs, membership fees, and spirit tablets' admission charges to accumulate considerable funds that their managers could proceed to lend out cheaply to lineage members or more expensively to non-lineage members," the lineage institution "provided financial backing not only to commercial and financial partnerships in Huizhou villages but also to smaller Huizhou merchants' expansion into

\footnotetext{
${ }^{91}$ Prasenjit Duara, Culture, Power, and the State: Rural North China, 1900-1942 (Stanford: Stanford University Press, 1988), 246.

${ }^{92}$ Faure, Emperor and Ancestor, 9.

${ }^{93}$ Aminzade, "Historical Sociology and Time," 463.

${ }^{94}$ Szonyi, Practicing Kinship, 201.
} 


\section{Song Chen}

the markets and pawnshop operations in the lower Yangzi delta." The lineage's engagement in commerce was of vital importance, since it helped the lineage alleviate - if not completely resolve - the perennial tension between its growing membership and limited collective resources. The profits that these ancestral halls accrued from these commercial activities, McDermott continues, "helped to pay for the ancestral worship rituals that lineage elders practiced in part to please their ancestors and in part to retain the loyalty of fellow lineage members, on whose donations, admission charges, usage fees, and interest payments they heavily depended" $(6,432) .{ }^{95}$ This symbiotic relationship between local institutions and commerce was not unique to Huizhou or to lineage organizations. Everywhere from Guangdong to Shanxi and from village worship associations to gentry societies, revenues from moneylending and rental property funded the activities of these institutions. Village worship associations in southern Shanxi received generous donations from wealthy merchants and supplemented their income through moneylending and rental businesses ( $\mathrm{Du}, 226-27)$. The Dakui Hall, the institutional mainstay of the Foshan gentry, financed its activities with, among others, rental income from its shops and land in front of the Beidi Temple and around the town's main wharf. ${ }^{96}$ Last but not least, in the increasingly interconnected relationship between local authority derived from degrees and official rank awarded by the imperial state and that from the domination of local institutions, wealth provided the last piece in this jigsaw puzzle. As wealthy local merchants, on the one hand, bolstered their position in lineages and village worship associations by underwriting a substantial proportion of the expenses, and on the other hand, purchased degrees for themselves and invested in the education of their descendants for the examinations, the boundaries between gentry and non-gentry and between different sources of prestige and authority became increasingly fluid.

Thus, the new local order-that is, the spread of property-holding, self-governing local institutions under gentry leadership or influence-emerged out of the mutually constitutive interplay between social structure and social action that unfolded over several centuries from the Song to the Ming-Qing. Long-term structural changes from the Song onward, especially economic expansion and population growth, presented a challenge for effective governance. But they also provided resources for new forms of local organization and new approaches to local administration. The growth of commercial wealth and the spread of print culture provided support for social and political decisions that contributed to the continuous expansion of a locally rooted, educated elite and the proliferation of self-governing local institutions, which then served as the organizational interface between the imperial government and its subjects, giving rise to new dynamics between state and local society.

\footnotetext{
${ }^{95} \mathrm{McDermott}$ plans to take up this issue in great detail in the subsequent volume of The Making of a New Rural Order. But he has offered some discussions on the relationship between lineage organizations and Huizhou merchants' far-flung business empire in an earlier article. See Joseph P. McDermott, "The Rise of Huizhou Merchants: Kinship and Commerce in Ming China," in The Economic History of Lower Yangzi Delta in Late Imperial China: Connecting Money, Markets, and Institutions, edited by Billy Kee-long So (London: Routledge, 2013), 233-66.

${ }^{96}$ Rankin, "Managed by the People," 13-24.
} 